ARTIKKELI

\title{
UUden SHERLOCKIn UUdENLAISET FANIT
}

\author{
Fanius osana digitaalista mediatuotantoa
}

Tanja Sihvonen ja Meniina Wik

$\mathrm{K}_{\mathrm{t}, \mathrm{sen}}$ Ittuurintutkimuksen keskeisiä tutkimuskohteita ovat erilaiset kulttuuriset esitykset ja näyttämöt, joihin myös fanien toiminta voidaan lukea. Yhä laajenevassa teoreettisessa keskustelussa digitaalisista tuotannon ja kulutuksen tavoista sekä tuottajien ja kuluttajien rajojen hämärtymisestä fanit ovat merkittävässä asemassa: he tekevät ihailemansa mediatekstin tuotannon ulkopuolella jatkuvaa taustatyötä ja aineiston uudelleentulkintaa (ks. esim. Caro Lancho 2013; Duffett 2013, 170; Hills 2012, 41; Jenkins 1992, 45, 63-65, 86; Nikunen 2005, 150). Usein he myös jakavat mielellään faniutensa käytäntöjä toisten ihailijoiden kesken, ja näin faniyhteisöt ja -kulttuurit ylläpitävät itse itseään.

Itseilmaisullisen funktionsa lisäksi fanituotanto asettuu kiinnostavilla tavoilla osaksi globaalia mediateollisuutta, ovathan laajimmalle levinneet faniuden kohteet usein transnationaalisia eli kulttuuri- ja kielirajat ylittäviä suuria tuotantoja. Yksi fanien tuottama aineistomuoto on fanifiktio, narratiivi, joka työstää kulttuurituotteen esiin nostamia teemoja eteenpäin ja uusiin suuntiin. Fanifiktio on digitaalisen ajan kansankulttuuria, jota jaetaan, käsitellään ja kommentoidaan internetissä (esim. Koski 2011). Tämä toiminta asettuu väistämättä osaksi digitaalisen mediatuotannon logiikkaa, sillä tuotantoyhtiöt eivät voi jättää faneja tai faniuden toimintatapoja huomiotta suunnitellessaan kulttuurituotteisiin sisäänkirjoitettuja puhutteluja, kerronnallisia jatkumoita, henkilöhahmoja ja itse tuotteiden levitystä.

Faneja, faniuden käytäntöjä ja fanituotantoa voidaan ottaa osaksi mediatuotteiden suunnittelua myös tietoisesti, ja oletettavaa on, että näin tapahtuu yhä lisääntyvässä määrin. Tässä artikkelissa tarkastelemme näiden eri tuotannon tapojen välistä rajapintaa pohtimalla yhtäältä, miten fanit on otettu huomioon tv-sarja Uuden Sherlockin (Sherlock, 2010-; tästä lähtien US) narratiivissa eli sen kerronnallisissa rakenteissa, ja toisaalta, miten fanit vastaavat heitä puhuttelevaan sisältöön. Taustoittaaksemme analyysiamme tarkastelemme Sherlock Holmesiin liittyvää faniutta myös laajemmin. Uusi Sherlock on oiva tutkimuksen kohde pohjautuessaan yli 120 vuotta olemassa olleeseen fiktiiviseen hahmoon, jonka faneja on osallistettu sen ympärille rakentuvaan kerronnalliseen universumiin lähes alusta saakka. Jo ikonisen mestarietsivän luojan, brittiläisen kirjailijan Arthur Conan Doylen työssä näkyi lukijoiden antama palaute. Sherlock-tarinoita julkaistiin alunperin jatkokertomuksina 
Tanja Sihvonen ja Meniina Wik: Uuden Sherlockin uudenlaiset fanit

[http://www.elore.fi/arkisto/2_17/sihvonen_wik.pdf]

Strand-aikakauslehdessä (The Strand Magazine, 1891-1950), ja lukijoiden lähettämät kirjeet vaikuttivat monin tavoin Conan Doylen luomiin juonikuvioihin ja tarinoiden jatkumoihin (Biography 2016). Hänen oli muun muassa herätettävä kuollut Sherlock Holmes uudelleen henkiin fanien pettymystä lieventääkseen.

Conan Doylen alkuperäisten tarinoiden jälkeen Sherlock Holmes -hahmo on seikkaillut lukemattomissa erilaisissa adaptaatioissa. Jättimenestykseksi osoittautunut Uusi Sherlock on brittiläinen BBC:n ja Hartswood Filmsin tuottama televisiosarja, joka on kirjoittamishetkellä yltänyt neljänteen tuotantokauteensa. Se koostuu yhteensä kahdestatoista 90-minuuttisesta jaksosta. Sarja on toimiva yhdistelmä uutta ja vanhaa: Sherlock Holmes asuu edelleen Lontoon Baker Streetilla, hänen apunaan, asuintoverinaan ja ystävänään toimii tohtori John Watson, ja vuokraemäntänään häärii rouva Hudson. Tuttu on myös työnkuva: Holmes toimii Suur-Lontoon poliisitoimen, Scotland Yardin, konsultoivana etsivänä, ja hänen ylivertainen älynsä tekee hänestä työssään korvaamattoman. Uskollisuus Conan Doylen tuotannolle näkyy sarjassa monin tavoin, ja sen luojat ovatkin korostaneet omaa fanitaustaansa ja Holmes-kaanonin tuntemustaan (ks. Ward 2014). Kiinnostavaa on, että Uusi Sherlock onnistuu olemaan sekä uskollinen alkuperäistekstille että uskottavasti digitaalisen aikakauden tuote (Stein \& Busse 2012, 21-22).

Uusi Sherlock jatkaa pitkää Sherlock-sovitusten perinnettä osallistamalla faneja itse tuotantoon ja myös vie sitä aiempaa pidemmälle sulauttamalla fanifiktion piirteitä jopa omiin kerronnan keinoihinsa. Koska koko Sherlock-universumi on rönsyilevyydessään tutkimuksen kohteena liian laaja käsiteltäväksi yhdessä artikkelissa, olemme valinneet aiheeksemme pienen juonellisen yksityiskohdan, joka tarjoaa mahdollisuuksia purkaa hahmottelemiamme fanikulttuurisia kytkentöjä. Keskitymme tässä artikkelissa Sherlock-hahmon kuolemaan - tai oikeastaan Sherlockin toistuviin kuolemiin ja henkiin heräämisiin - sekä tämän syklisen rakenteen hahmottamiseen suhteessa fanikäytäntöihin ja fanien siitä tuottamiin tulkintoihin. Alkuperäisessä Conan Doylen tarinassa Sherlock Holmes kuoli pudotessaan vesiputoukseen kamppailtuaan perivihollisensa James Moriartyn kanssa. US:ssa ja fanifiktiossa putoukseen viittaava nimi, The Reichenbach Falls (tai Fall), viittaa nimenomaan Sherlockin kuolemaan.

Tutkimuksemme taustaoletus on, että Sherlock Holmesin pitkään jatkunut suosio selittyy hahmon arvoituksellisuudella ja monitulkintaisuudella sekä "huokoisuudella", joilla viittaamme hahmoa määrittävien ominaisuuksien ohuuteen ja tulkinnanvaraisuuteen (ks. Hills 2014, 7-10). Näistä perusaineksista on rakennettu Conan Doylen tarinoiden varaan valtava määrä erilaisia mediatuotantoja, joiden kautta on syntynyt erilaisia fanikerrostumia. Uusi Sherlock on luonut yhden uuden fanikerrostuman, joka työstää tv-sarjaa digitaalisen aikakauden tuotteena ja ymmärtää sen tarjoaman tarttumapinnan antamat mahdollisuudet. US onkin tv-sarjana poikkeuksellisen tietoinen herättämästään kiinnostuksesta, minkä takia sen tarkastelu fanikulttuurisessa kehyksessä on erityisen palkitsevaa. Kutsumme tässä työssä lukuisten Sherlock Holmes -mediatuotantojen sekä niihin kytkeytyvien fanikäytäntöjen yhdessä muodostamaa kokonaisuutta kerronnalliseksi universumiksi. 
Televisiosarjan tuotannon ja fanituotannon välisten kytkösten tarkastelu on ajankohtaista tämänhetkisessä mediamaisemassa, sillä sosiaalinen media toimii ikään kuin moukarina huojuttaen tuottajien ja kuluttajien välistä seinämää. Tiedon välittyminen näiden kahden puolen välillä on helpompaa ja nopeampaa kuin koskaan aikaisemmin. US myös ojentaa katsojiensa käyttöön valmiita hashtageja eli aihetunnisteita (esimerkiksi \#sherlocklives) ja www-osoitteita keskustelun sytykkeeksi sosiaalisessa mediassa sekä laajentaa tarinamaailmaansa eri medioiden ja fanituotannon alustojen kautta. Näin tuotanto ohjaa fandomin eli faniyhteisöjen liikehdintää omien intressiensä mukaiseen suuntaan ja luo samalla fanien keskuudessa osallistuvuuden tunnetta. Toisaalta myös fanien voidaan olettaa vaikuttavan kaupalliseen tuotantoon sekä suoraan että epäsuorasti.

Tässä artikkelissa keskitymme tarkastelemaan fanien toimintaa ja osallisuutta US-sarjan kerronnallisiin rakenteisiin edellä mainitun kaltaisten esimerkkien kautta. Tutkimme yhtäältä sitä, miten tv-sarja puhuttelee faneja ja ottaa heidät huomioon, ja toisaalta sitä, miten fanit vastaavat tuotannon heille asettamiin "täkyihin". Tutkimusaineistomme koostuu US:n kahdesta jaksosta sekä niihin kytkeytyvästä, internetissä levitettävästä fanituotannosta. Keskitymme Sherlockin (lavastettuun) kuolemaan sarjan toisen tuotantokauden kolmannessa (S2E3) eli viimeisessä jaksossa Loppunäytös (engl. The Reichenbach Fall) sekä kolmannen tuotantokauden ensimmäisessä jaksossa Tyhjä ruumisauto (engl. The Empty Hearse). Lisäksi tarkastelemme fanien tuottamaa materiaalia, joka viittaa näissä kahdessa jaksossa käsiteltyyn Sherlockin kuolemaan. Loppunäytös (S2E3) esitettiin Britanniassa 15.1.2012 ja Tyhjä ruumisauto (S3E1) puolestaan 1.1.2014, ja kaikki tarkastelemamme videomuotoinen fanituotanto ajoittuu näiden päivämäärien väliseen ajanjaksoon (ks. kuvio 1). Videoiden lisäksi analysoimme myös teksti- ja kuva-aineistoa, jonka julkaisuajankohta ei ole näin tarkkaan määritelty, mutta joka temaattisesti kytkeytyy Sherlockin kuolemaan ja siten jaksoihin S2E3 ja S3E1.

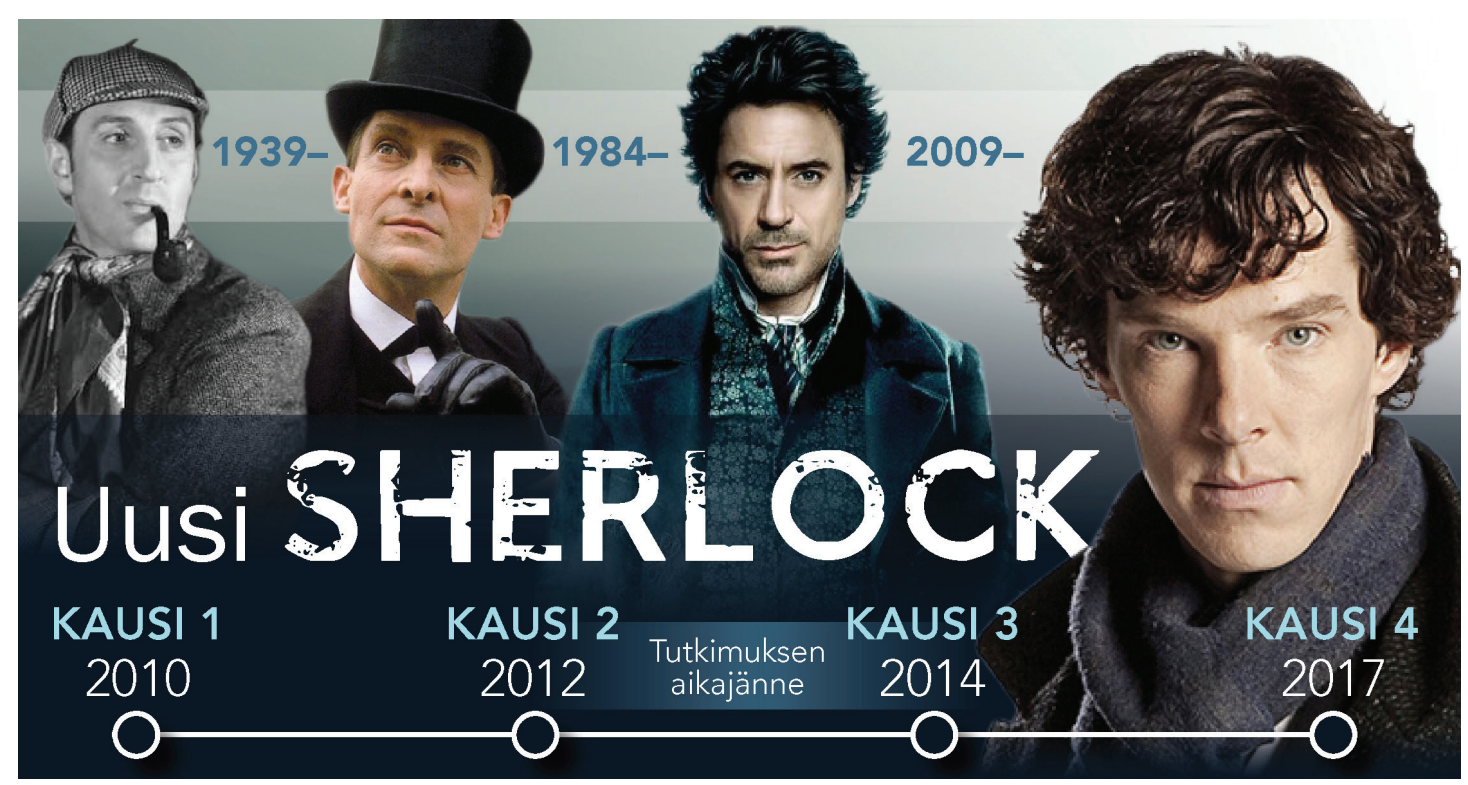

Kuvio 1. Uusi Sherlock -televisiosarjan tuotantokausien julkaisuvuodet sekä tutkimuksessa tarkasteltavan fanituotannon ajanjakso. 
Käytämme siis aineistonamme sekä tv-sarjaa ja siinä esiintyviä hahmoja että internetissä jaettua fanituotantoa ja siihen liittyviä keskusteluja. Alustat, joilta aineisto on kerätty, ovat videopalvelu YouTube, mikroblogipalvelu Tumblr ja taideyhteisö DeviantArt. Alustojen lisäksi olemme keränneet materiaalia Google-hakukoneen kautta etsien erilaisiin yleisiin, tunnettuihin meemeihin perustuvia Sherlock- ja Reichenbachin putous -aiheisia mukaelmia. Tutkimusmateriaalimme koostuu teksteistä, kuvista ja audiovisuaalisesta aineistosta, ja tarkastelemme sitä lähiluvun (close reading) avulla. Lähiluvulla tarkoitetaan yksityiskohtaista tekstin lukemisen menetelmää; sen avulla liikutaan temaattisia aineksia analysoimalla yksityiskohdista kohti kokonaisuutta ja kokonaismerkitystä, ja sitä voi soveltaa kirjoitetun tekstin lisäksi myös visuaaliseen, äänelliseen ja materiaaliseen aineistoon (Pöysä 2015, 6, 28; Vanhanen 2015).

Kiinnostuksemme kohdistuu tekstuaaliseen Sherlock Holmesin hahmoon, joka sekä konkreettisesti eli mediatuotteena että symbolisesti, fanien tekemän työn tuloksena, herää yhä uudelleen ja uudelleen henkiin. Ennen US-sarjaan ja Sherlockin hahmoon kytkeytyvän faniuden analyysia luomme katsauksen fanitutkimuksen perinteisiin ja käytäntöihin. Perustelemme erityisesti sitä, miksi fanien tuottaman visuaalisen ja audiovisuaalisen aineiston tutkiminen on tärkeää. Näin pääsemme rakentamaan kuvaa siitä, miten fanit toimivat kulttuurituotteiden jatkumon takaajina luoden omissa verkostoissaan affektiivisesti eli tunnereaktioihin vedoten leviävää ja uudelleenmuotoutuvaa kansankulttuuria. Osana tätä tavoitetta tarkastelemme artikkelin lopussa myös sitä, onko fanin representaatio tv-sarjassa muuttunut varhaisemmasta populaarikulttuurin perinteestä tutusta fanaattisesta ja itsekontrollinsa menettäneestä ihailijasta (ks. esim. Stanfill 2013), vaikka fanituotannon positiiviset ja luovat aspektit tuotantokoneiston puolella tunnustetaankin. Näin voimme artikkelin lopussa vetää yhteen havaintomme yhtäältä Sherlockin kuolemaan liittyvästä fanituotannosta ja toisaalta niistä tavoista, joiden avulla Uusi Sherlock fanituotantoa tukee, ja päättää tutkimuksemme kokonaisnäkemykseen fanituotannon merkityksestä tv-sarjan muotoutumisessa ja sen suosion takaamisessa.

\section{FANitUtKIMUKSEN PERINNe JA FANIUDEN TOteUtTAMINEN}

Termi "fani" juureutuu latinan kielen sanaan fanaticus, joka tarkoittaa alkuperäisessä kontekstissaan temppelipalvelijaa tai uskollista kannattajaa. Siihen liitettiin pian myös negatiivisia konnotaatioita - sillä viitattiin esimerkiksi hallitsemattomaan kiihkomielisyyteen. Termi kytkeytyi osaksi yhdysvaltalaista musiikki- ja teatteritaiteen tähtijärjestelmää jo 1800-luvun alkuvuosikymmeninä, kun eri alojen esiintyjien ihailijat perustivat ihailijakerhoja ja kirjoittivat fanikirjeitä. (Jenkins 1992, 12; Nikunen 2005, 17.) Vaikka fanius ja faniuden käytännöt yleistyivät 1900-luvun kuluessa, aihepiirin tutkimus, ja nimenomaan faniuden tarkastelu arkipäiväisenä ilmiönä, alkoi vasta 1990-luvulla (Jensen 1992, 13). Fanitutkimuksen klassikko on Henry Jenkinsin Textual Poachers (1992), joka haastoi ilmestyessään stereotypioita esittäen fanit tuottavina ja luovina yksilöinä ja korostaen fanikulttuurien monimuotoisuutta. Teos sai jopa oman fanikuntansa ilmestyessään aikana, jolloin populaaria tiedejulkaisemista alettiin korostaa (Duffett 2013, 15-16). Jenkinsin kirjasta käynnistyi uusi kulttuurisen fanitutkimuksen perinne, joka korosti aktiivista fanikuvaa ja pyrki näyttämään faniyhteisön positiivisessa valossa aiemman 
tutkimuksen fokuksessa olleen kritiikittömästi ihailunsa kohteeseen suhtautuvan hysteerikko-fanin sijaan. Nykyään fanitutkimus on monitieteinen risteyskenttä, jota tutkijat lähestyvät erilaisten metodologioiden kautta (Evans \& Stasi 2014, 6). Faniutta on hedelmällistä tarkastella roolina, jonka voi ottaa tai jota voi toteuttaa monin tavoin ja yhtä hyvin niin online- kuin offline-tiloissakin. Sitä kanavoidaan esimerkiksi kirjoittamalla fanifiktiota eli faniuden kohdetta hyödyntävää tekstiä ja tekemällä fanitaidetta, kuten videoita, musiikkia, piirroksia ja maalauksia. Suosittua on myös fanzinejen eli erikoistuneiden fanilehtien valmistaminen ja lukeminen, bloggaaminen sekä cosplay eli pukuilu, jossa fani omaksuu faniutensa kohteen olemuksen pukeutumistyyliä myöten. Nimikirjoitusten metsästäminen ja vaikkapa konsertissa huutaminen ja taputtaminen ovat osa performanssia, jonka kautta omaa henkilökohtaista faniutta tuodaan julkisesti nähtäväksi (Duffett 2013, 178, 186-188). Nykyisessä mediamaisemassa merkittävässä asemassa faniuden toteuttamisympäristönä ovat myös verkkokeskustelut ja -forumit. Televisiosarjojen faniyhteisöjä ovat aikaisemmin rytmittäneet sarjojen tuotantoaikataulut ja jaksojen saatavuus, mutta nykyään erimuotoiset tallenteet, ohjelmien lataaminen ja suoratoistopalvelut ovat helpottaneet faniuden irtautumista ajallisista kehyksistä (ks. Nikunen 2008, 190). Huomioitavaa on, että vaikka aktiivista fanituotantoa ja sen merkitystä fandomissa korostetaan, varsin suuri osa näistä tuotteista nauttivista henkilöistä toimii pääasiassa yleisön ja seuraajan roolissa. Tutkijoiden tarkastelun kohteeksti on lisäksi valikoitunut usein yhteisöllisessä fandomissa toimiva fani itsenäisesti toimivien sijaan (Coelho 2011, 81).

Tutkimusmateriaalissamme näkyy voimakkaana fanituotannon (audio)visuaalisuus, jonka merkitys alkoi nousta 1970-luvulla kotikäyttöön tarkoitettujen videonauhureiden yleistymisen myötä. Fanit ottivat nopeasti videon omakseen. Kun videolaitteet arkipäiväistyivät ja media-aineistoja alkoi olla aiempaa paremmin saatavilla, videoiden katseluajankohta vapautui ja faniuden toteuttaminen videomuodossa tuli entistä houkuttelevammaksi (ks. Jenkins 1992, 71). Fanit muokkasivat saatavilla olevista materiaaleista esimerkiksi mash-up-videoita, joita esitettiin kokoontumisissa. Niiden sisällön muodostivat yhteisössä jaetut kiinnostuksen kohteet ja kollektiiviset fantasiat. Videot saattoivat esimerkiksi nostaa esiin subtekstejä ja korostaa sivuhahmoja niiden ympärillä pyörivine tarinoineen. Videot toimivat ikään kuin tulkinnallisina linsseinä, jotka auttoivat näkemään lähdetekstin uudella tavalla. Kuitenkin suurinta kotivideoteknologian mahdollistaman tuotannon aaltoa saatiin vielä odottaa. (Duffett 2013, 11-12; Jenkins 1992, 248-248, 237, 239; Coppa 2008.)

1990-luvun alun tutkimuksessa fanien kerrottiin vaihtelevan itse koostamiaan videoita (songtape) sekä postitse että fanitapaamisten aikana (ks. Bacon-Smith 1992, 1799). 2000-luvulla tämän käytännön on pitkälti korvannut videopalvelu YouTube, jossa fanit jakavat omaa audiovisuaalista tuotantoaan. Kuka tahansa voi perustaa palveluun oman kanavan, jonne voi tallentaa videoita joko omaan käyttöönsä, jakaa niitä julkisesti nähtäville tai varata niitä ainoastaan oman ystäväpiirinsä katsottavaksi. Maailman tunnetuin ja käytetyin videoiden jakamiseen keskittyvä verkkosivusto YouTube on yksinkertaisesti kategorisoiden vain videopalvelu, mutta siinä tehdään hakukone Googlea lukuunottamatta kuukausittain enemmän hakuja kuin missään yleisessä hakukoneessa. Jo tällaisista luvuista saa viitteitä nettivideoiden suuresta suosiosta. (Aalto \& Uusisaari 2009, 54-55, 63.) Vaikka YouTube ei 
itsessään ole luova voima, toimii se tällä hetkellä tehokkaana fanien luovan voiman kanavoijana. YouTubesta, kuten koko internetistä, on muotoutunut fanituotannon säilytyspaikka ja samalla kulttuurisen pääoman jakamiseen ja sosiaaliseen osallistumiseen houkutteleva alusta. (Ks. Duffett 2013, 236-237.) Se toimii nykyaikaisena kansankulttuurin toimintakenttänä, jossa osaa käyttäjien editoimasta aineistosta voi tarkastella ikään kuin digitaalisena folklorena (Koski 2011, 14). Internet- ja fanikulttuurin tärkeän osan muodostaa edelleen remix-kulttuuri, jossa olemassa olevaa materiaalia remiksataan eli työstetään uudelleen käyttäjän omaksi luomukseksi (Logan 2010, 70). Tällöin faneille avautuu tilaisuus onnistuneen editoinnin ja musiikkivalintojen kautta tuoda oma näkemyksensä esiin videoon rakentamiensa tarinoiden kautta. Esimerkiksi Uudesta Sherlockista on olemassa pelkästään YouTubessa valtava määrä visuaalista fanituotantoa, joka on rakennettu raakamateriaalina toimivasta kaupallisesta mediatekstistä eli tv-sarjasta.

Marshall McLuhan esitti Understanding Media -teoksessaan (1964) yhden mediumin sisällön olevan aina toinen media - esimerkiksi kirjoituksen sisältö on puhetta. Jay Bolter ja Richard Grusin (2000, 45, 57, 60) vievät ajatusta eteenpäin esittäessään, että mediumin ottaessa uuden muodon lopputuloksena ei synnykään media, vaan remedia: aikaisempi media muuttaa muotoaan ja käy läpi evoluution uudeksi, entistä monimuotoisemmaksi ja aikaisemman versionsa puutteita korjaavaksi mediaksi. Esimerkkinä Bolter ja Grusin käyttävät kielellistä mediaa, jota nyttemmin haastaa (audio)visuaalinen media. Konvergenssiin perustuvassa digitaalisessa mediamaisemassa remediaatiolla on hedelmällinen maaperä, mikä näkyy myös fanituotannossa - perinteinen kirjoitettu fanifiktio on muuttumassa kuvakerronnaksi, visuaalisiksi esseiksi (ks. Koski 2011, 23-24). YouTube ja blogit tarjoavat suositun alustan ja tilan näiden visuaalisten esseiden jakamiselle, mutta samaa toimintamuotoa ilmentävät myös esimerkiksi meemit, jotka leviävät tehokkaasti sosiaalisessa mediassa. Näin erityisesti meemejä voi ajatella modernina kansanperinteenä, jossa jaetut normit ja arvot rakentuvat kulttuuristen artefaktien, kuten kuvankäsittelyohjelmalla muokattujen kuvien kuvien tai kaupunkitarinoiden kautta (Shifman 2014, 15). Tällaisen internet-välitteisen kansankulttuurin tutkimuksen ja analysoimisen haasteena on sen epävakaus: digitaalisesti toimivan "kansan" keskuudessa ideat muuttuvat nopeasti ilmentymästä toiseen ja leviävät samanaikaisesti useiden eri kanavien kautta. (Heimo \& Koski 2014, 4.)

Fanituotannosta puhuttaessa ei voida sivuuttaa fanien ja mediatekstien takana olevan tuotannon välistä suhdetta. Tekijänoikeuskysymykset vaikuttavat faniuden toteuttamisen käytäntöihin, sillä fanien kiinnostuksen kohteet, hahmot ja tarinat, ovat aina lähtökohtaisesti jonkun toisen omistuksessa. Suhtautuminen asiaan on kaksijakoista. Jotkut tuottajat kannustavat fanituotantoon ja toiset yrittävät kitkeä sen pois tulkiten sen tekijänoikeuksien rikkomiseksi. Mark Deuze (2007, 244-245) näkee globaalin osallistavan mediakulttuurin eli tuottamisen ja kuluttamisen konvergenssin johtavan luovuuden ja massaviihteen kohtaamiseen, eli todellisten tai kuviteltujen rajojen hämärtymiseen tekijöiden ja käyttäjien välillä. Hänen mukaansa on isojen yhtiöiden etujen mukaista kontrolloida tuottajiksi muuttuneiden kuluttajien toimintaa ja seurata heidän mielipiteitään. Samalla tuottajat kuitenkin varmistavat, että tekijänoikeuksien kaupallinen hyödyntäminen säilyy omissa käsissä. (Deuze 2007, 247, 259.) Myöskään kaikki fandomit eivät suhtaudu 
fanituotantoon suopeasti. Joissain tapauksissa esimerkiksi fanifiktion kirjoittaminen nähdään hahmojen väärinkäyttönä ja "hahmoraiskauksena" eli vääristelynä, joka kohdistuu yhteisön hyväksynnän jo saaneisiin tarinoihin ja hahmoihin (Jenkins 2006, 57). Fanituotanto näyttäytyy kaiken kaikkiaan kompleksisena, monenlaisten tunnereaktioiden motivoimana ja valtataistelujen määrittämänä kenttänä, jota voidaan tulkita sekä yksilöiden että yhteisöjen toiminnan kautta. Uuteen kukoistukseen internetin myötä noussut fanituotanto on digitaalisen ajan kansankulttuuria, joka ei säily kulttuuristen toimijoiden keskuudessa sellaisenaan, annettuna, vaan joka muotoutuu käyttäjiensä käsissä aina uuteen muotoon (Koski 2011, 24-26). Näiden muutosten tulkitsemiseen oman haasteensa lisää se, että ne voivat olla hyvinkin pieniä ja hienovaraisia mikroliikkeitä, jotka hiljalleen tekevät alkuperäisestä tuotteesta erilaisen ja sallivat jokaisen käyttäjän jättää prosessiin oman jälkensä. Toisaalta kaiken fanituotannon keskiössä on se suhde, jota fanit työstävät suhteessa ihailunsa kohteeseen. Fanituotannon käytännöt eivät siis ole pelkästään uudistavia, vaan myös konservatiivisia, säilyttäviä. Tarkastelemassamme tapauksessa sekä fanituotannon uudistavat että säilyttävät pyrkimykset kohdistuvat jo varsin iäkkääseen Sherlock Holmesin hahmoon ja tämän fiktiivisen hahmon ympärille syntyneeseen kerronnalliseen universumiin.

\section{Sherlock Holmesin syntymä JA KUOlema}

On todennäköistä, että jokaisella meistä on jonkinlainen mielikuva Sherlock Holmesin hahmosta. Hahmon kuvaukseen sisältyy sekä ulkoisia tunnusmerkkejä (pituus, deerstalker-hattu, piippu, pitkä takki) että sisäisiä ominaisuuksia (sisäänpäinkääntynyt, erikoinen persoona, lyömätön loogisten johtopäätösten tekijä). Sherlockin hahmon ulkoiset tunnusmerkit ovat peräisin Strand-lehden kuvittajan Sidney Pagetin piirroksista. Toisin kuin Conan Doylen teksteissä, piirroksissa Sherlock kuvataan salskeana ja hienostuneena miehenä, ja käytännössä jokaista Sherlockia esittänyttä näyttelijää on sittemmin verrattu tähän malliin (Ward 2014). Uuden Sherlockin päähenkilö ei polta piippua, ja hän uudistaa muutenkin konventioita esimerkiksi käyttämällä deerstalker-hattua ainoastaan pakoillessaan paparazzeja. Ulkoisesti roolin odotukset täyttävä näyttelijä Benedict Cumberbatch on pitkässä takissaan jotain jokamiehen ja bisnesmiehen väliltä, osa sekä uutta että vanhaa maailmaa (ks. Evans 2012, 110). Roolittaminen on tärkeä tekijä US:n kaltaisen sarjan suosion rakentumisessa, sillä mediatekstissä "vääränlaisena" kehona ja siten ikään kuin väärintulkittuna Sherlockia ei helposti hyväksyttäisi. Tuskin yksikään audiovisuaalisessa muodossa nähty Sherlock Holmes -adaptaatio on säästynyt fanien esittämältä kritiikiltä liittyen Sherlockin esittäjään (Polasek 2012, 45).

Arthur Conan Doylen luomasta mestarietsivästä on sen yli 120-vuotisen olemassaolon aikana muotoutunut salapoliisiuden symboli, johon kaikkia yksityisetsiviä tai sellaisiksi haluavia suhteutetaan. BBC:n versiossa esiintyvä Sherlock Holmes on alkuperäisestä kontekstistaan uloskirjoitettu ja uudelleentulkittu hahmo. Hän käyttää sujuvasti apunaan 2000-luvun tietotekniikkaa ja internetiä, joiden tarkoitus on hänen mukaansa tiedonetsintä inmissuhteiden ylläpitämisen sijaan. Hän on selvästi moderni, tämän vuosituhannen henkilö, joka viihtyy älypuhelin kädessä laajentaen "mielen palatsiaan" digitaaliseen pilveen, kuitenkaan päättelykykyään laiminlyömättä. (Stein \& Busse 2012, 21-22; Kustritz \& Kohnen 2012, 94.) Uusi 
Tanja Sihvonen ja Meniina Wik: Uuden Sherlockin uudenlaiset fanit

[http://www.elore.fi/arkisto/2_17/sihvonen_wik.pdf]

Sherlock esittelee Holmes-hahmosta nykyaikaisen tulkinnan, mikä on yksi sen suosioon vaikuttava tekijä - sarjaa voi katsoa itsenäisenä tekstinä, eli siitä nauttiakseen katsojan ei tarvitse olla tutustunut Sherlock-kaanoniin (Polasek 2012, 48).

Kuten olemme todenneet, Sherlock Holmesin adaptiivisuus ja jatkuva suosio perustuvat suurelta osin hahmon fanikulttuurisiin kytkentöihin (ks. myös McLaughlin 2013). Kun Sir Arthur Conan Doyle 1800-luvun lopussa julkaisi ensimmäisen $A$ Study in Scarlet -nimeä kantavan Holmes-tarinansa, hän ajatteli itse ilmeisesti luovansa lähinnä kaupallista viihdettä ja toivoi niin sanottujen vakavampien, historiaa käsittelevien teostensa menestyvän vähintään yhtä hyvin (Biography 2016). Suurimman kirjallisen menestyksensä Conan Doyle saavutti kuitenkin juuri Sherlock Holmesin avulla, ja lopulta Holmes-kaanon tuli kattamaan kaikkiaan 56 novellia ja neljä romaania. Faniyhteisön muotoutumisen kannalta on merkittävä yksityiskohta, että Sherlock Holmes -tarinat ilmestyivät nimenomaan jatkokertomuksina. Seikkailu- ja jännityselementtejä hyödyntävän kerrontatavan lisäksi Conan Doylen kirjallista suosiota edesauttoi hänen saamansa lukijapalaute, ja kirjailijan ja hänen ihailijoittensa välistä kanssakäymistä voikin tulkita vuorovaikutteisen faniyhteisön synnyn näkökulmasta.

Vuosien 1887-1917 aikana Sherlock Holmesista tuli laajalti tunnettu kirjallinen hahmo, jonka suosio vaikutti vankkumattomalta. Conan Doylen on kuitenkin tulkittu olleen kyllästynyt hahmoonsa ja lukijoiden jatkuviin vaatimuksiin, joten hän päätti surmata etsivänsä kesken tämän kukoistavan menestyskauden: tarinassa The Final Problem (1893) Sherlock Holmes syöksyi alas Reichenbach-putoukseen yhdessä vihollisensa, tohtori James Moriartyn kanssa. Ratkaisu tuntui vahvaksi muotoutuneesta fanikunnasta käsittämättömältä, ja se aiheutti sekä laajaa paheksuntaa että protesteja. Sherlock-faniuden levinneisyydestä kertoo jotain se, että surutyötä tehtiin myös Britannian ulkopuolella (McLaughlin 2013). Jopa kaksikymmentä tuhatta Strand-lehden lukijaa perui tilauksensa kuultuaan, ettei mestarietsivä seikkailisikaan enää lehden sivuilla. Conan Doyle jatkoi kirjoitustyötä kohusta huolimatta. Kehitellessään The Hound of The Baskervilles -tarinaansa hän huomasi tarvitsevansa tarinaan sankaria ja päätti herättää Sherlock Holmesin henkiin. Vuonna 1901 etsivä oli jälleen elossa ja uusien tutkimusten parissa. (Biography 2016.)

Uusi Sherlock esittää oman näkemyksensä päähenkilön kuolemasta toisen tuotantokauden viimeisessä jaksossa (S2E3). Se käynnistyy synkissä tunnelmissa kuvaten psykiatrin vastaanotolla istuvaa John Watsonia, joka kertoo Sherlockin kuolleen. Jakso etenee Sherlockia täysissä sielun ja ruumiin voimissa seuraavien takaumien avulla. Katsoja saa odottaa jakson viimeiselle kolmannekselle asti saadakseen selville, mitä Watson tarkoitti ja miten tilanteeseen päädyttiin: selviää, että James Moriarty oli lavastanut etsivän syylliseksi useisiin rikoksiin. Langetettuaan poliisin, lehdistön ja kansan vihat Sherlockin niskaan, Moriarty uhkasi vahingoittaa Sherlockin läheisiä, jollei tämä tekisi itsemurhaa hyppäämällä Bartholomew'n sairaalan katolta. Teon myötä Sherlockin syyllisyys kävisi ilmeiseksi.

Nähdessään suunnitelmansa kulkevan vääjäämättömästi kohti toteutumistaan Moriarty riisti oman henkensä ampumalla itseään päähän kauhistuneen Sherlockin 
silmien edessä. Koska Sherlockin syyttömyyden ainoa todistaja oli nyt kuollut, ei hänelle jäänyt enää muuta vaihtoehtoa kuin astua sairaalan katon reunalle, soittaa hätääntyneelle Watsonille ja hypätä hyvästien jälkeen alas. Watson teki kaikkensa estääkseen teon, mutta joutui todistamaan maan pinnalta ystävänsä hyppyä (kuva 1). Jakso päättyy kohtaukseen, jossa murtunut Watson seisoo Sherlockin haudalla rukoillen ystävältään vielä viimeistä inmettä, joka toisi tämän takaisin. Watsonin poistuessa haudalta näkyy hautausmaan reunamilla tutun näköinen, tummaan takkiin verhoutunut hahmo, joka jakson viimeisillä sekunneilla paljastuu Sherlock Holmesiksi.

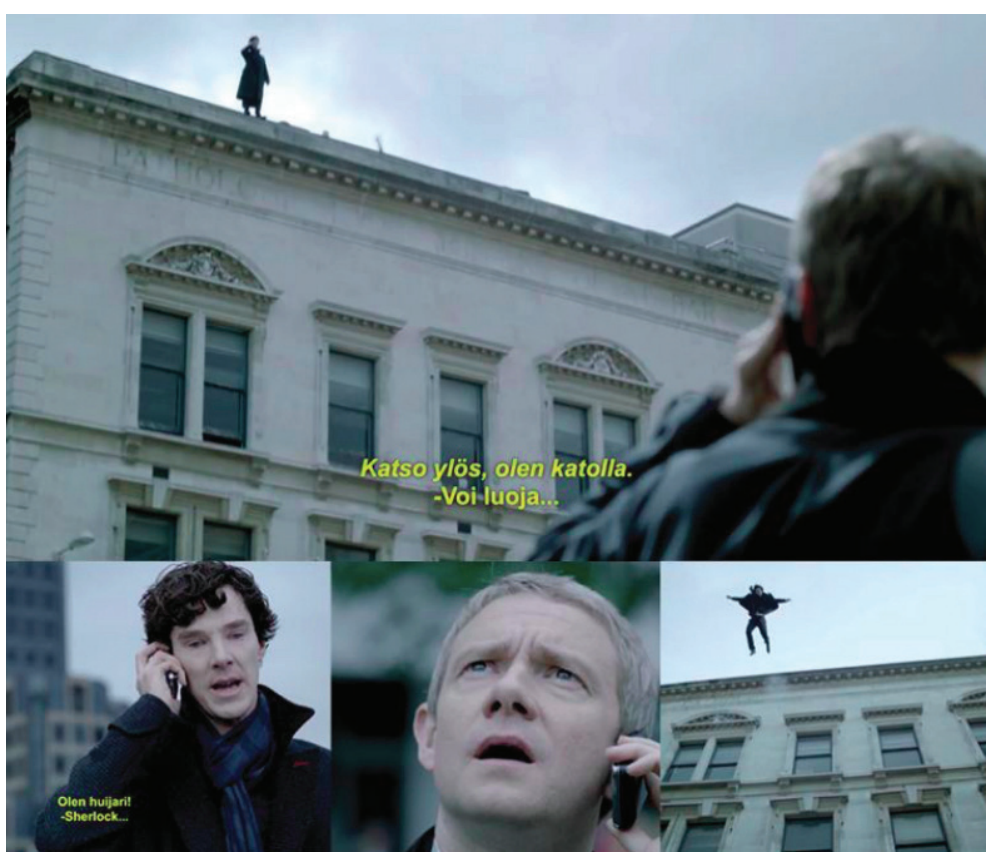

Kuva 1. Sherlockin ja Watsonin kohtaaminen ennen hyppyä.

Sherlock Holmesin tarinalle keskeisestä putoamiskuolemasta huolimatta Sherlock on sankarihahmo, jonka olemus on pohjimmiltaan kuolematon. Hän on maailman tunnetuin yksityisetsivä, jonka hahmo rakentuu yhä uusia yleisöjä puhuttelevista konnotaatioista. Jokaisen uuden adaptaation myötä Sherlock Holmes kokee uuden tulemisen, uuden reinkarnaation: Holmes-fandomissa hän on kuolematon, sillä jokainen uusi elokuva ja tv-sarja synnyttää hänet uudelleen ja tuo uuden yleisön hänestä tietoiseksi. Sherlock Holmes on ikään kuin kulttuurinen houkutin, joka tuo yhteen "sherlockiaanit" eli Sherlockiin keskittyvät fanit, sarjan tekijöiden muiden mediatekstien fanit, hahmoista ja niiden välisistä suhteista kiinnostuneet lukijat ja katsojat sekä sarjassa esiintyvien näyttelijöiden omat ihailijat. Paikkansa katsojakunnasta löytävät myös huoliteltua visuaalisuutta arvostavat television katsojat. (Hills 2012.)

Kuolemattomuuden ohella Holmesin hahmoa määrittelee monitulkintaisuus. BBC:n versiossa hän on lapsenomainen innostuja, joka on valmis riskeeraamaan oman henkensä välttääkseen tylsyyttä. Hänen mielenterveyttään on arvuuteltu; häneltä näyttäisi esimerkiksi puuttuvan taju oikeasta ja väärästä, mikä erottaa hänet viktoriaanisen ajan Sherlockista (Scott-Zechlin 2012, 60). Samoin kuin Conan Doylen tarinoissa, myös Uudessa Sherlockissa katsojan samaistumispintana toimii John Watson, jonka kautta hahmosta nousee esiin inhimillisyyttä, kuten yllä käsitelty kohtausesimerkki osoittaa. Watson on toiminut innoittajana myös fanifiktion kirjoittajille, sillä monissa tarinoissa Sherlock opettelee "ihmisyyttä" juuri Watson apunaan (Scott-Zechlin 2012, 65). Toinen Sherlockin hahmoa inhimillistävä tekijä on hänen kuvauksensa romanttisena sankarina, synkkänä hahmona, jolla usein on salaisuuksia ja joka suorastaan odottaa tulla pelastetuksi (usein niin sanotun tosirakkauden voimalla). Tämä voidaan suhteuttaa muihin sarjassa käsiteltäviin sankarimyytteihin: toimintasankariin, nykyaikaiseen oikean ja väärän rajapinnassa 
Tanja Sihvonen ja Meniina Wik: Uuden Sherlockin uudenlaiset fanit

[http://www.elore.fi/arkisto/2_17/sihvonen_wik.pdf]

operoivaan sankariin sekä klassiseen hirviönmetsästäjään (Evans 2012, 102-103; Barnett 2007). Sherlockin hahmon monitulkintaisuus ja sekä sankarin että antisankarin piirteiden yhdistäminen ovat toimineet merkittävinä tekijöinä häneen liittyvän faniuden ja faniyhteisöjen kehittymiselle.

\section{FANIYHTEISÖJEN MUOTOUTUMINEN}

Kiintymystä Sherlock Holmesin tapaisiin fiktiivisiin hahmoihin voidaan tulkita erilaisissa kehyksissä, mutta näyttää ilmeiseltä, että tietyt osatekijät Conan Doylen tarinoissa antoivat alkusysäyksen Sherlockiin keskittyvän faniyhteisön eli fandomin syntyyn. Fandomin syntyprosessi käynnistyy yleensä jaetuista arvoista ja ääneen lausumattomista olettamuksista, jonka jälkeen se alkaa toteutua yksilöiden mielissä ja johtaa lopulta yhteisöllisiin kokemuksiin. Faniuden ydinkokemukset voivat olla paitsi jonkin tietyn objektin tai henkilön ihailua myös ihailun tunteesta nauttimista eli mielihyvää tuottaviin kokemuksiin pyrkimistä (Duffett 2013, 278).

On sanottu, että fandom syntyy turhautumisen ja kiehtovuuden tasapainotilassa: jos mediateksti ei kiehdo meitä millään tavalla, emme koe tarvetta kiinnittyä siihen ja syventää katselukokemustamme. Jos taas mediateksti ei turhauttaisi meitä jollain tavalla, mikään siinä ei ajaisi meitä uudelleentulkitsemaan tai -tuottamaan sitä. (Jenkins 2008, 258.) Faneja voidaankin ajatella myös kiinnostuksensa kohteen suurimmiksi kriitikoiksi, jotka näkevät alkuperäisen tuotteen käytettävissään olevana raakamateriaalina, jossa riittää aukkoja täydennettäväksi. Luovilla uudelleentulkinnoillaan he haluavat tavoitella tunne-elämyksiä eli affekteja, luoda uusia dialogeja ja vapauttaa yhteisöllisen toiminnan kautta mediatekstien "uinuvia mahdollisuuksia" (Duffett 2013, 73). Tv-sarjojen tuotannoissa yleisöjen käsittäminen faneina merkitsee tiettyjen elementtien korostumista. Sarjat voivat esimerkiksi olla entistä monimutkaisempia viitatessaan tarinoiden taustoihin ja ennakkoon tiedossa oleviin hahmojen rakennusaineksiin. Tuotanto voi olla suorastaan riippuvainen siitä, että yleisö tuntee hahmojen historiaa ja löytää erilaisten fiktiivisten universumien risteymät sekä sisäänrakennetut vitsit ja mediaviittaukset (Nikunen 2005, 109).

Yksi tapa tarkastella tätä mediatekstien tuotannon ja fandomin risteävää ja lomittuvaa tekstikäsitystä on jako kaanoniin ja faanoniin. Kaanon voidaan määritellä alkuperäiseksi tekstiksi ja siihen hyväksytysti kuuluvaksi materiaaliksi. Eri tekstien kaanonit ovat ikään kuin keinoja herättää yleisöjä ja houkutella heidät osaksi niiden luomaa tekstuaalista universumia. Faanon taas on fandomin oma kaanon, joka muodostuu fanien näkemyksistä, uudelleentulkinnoista ja materiaalin alkuperäisestä poikkeavasta jäsentämisestä (ks. Scodari \& Felder 2000). Sherlock Holmes -fanikulttuurin syntyä sekä jakoa kaanoniin ja faanoniin kuvastaa faniyhteisön voimin syntynyt ja yhä täydentyvä tekstikokoelma The Grand Game, jonka tarkoituksena on selittää ja tulkita Holmes-tarinoita mahdollisimman yksityiskohtaisesti. Sen sisältö koostuu sekä tieteellisistä julkaisuista että fanien omasta ja keskenään jakamasta tuotannosta.

The Grand Game lähtee siitä oletuksesta, että Holmes ja John Watson ovat olleet todellisia historiallisia henkilöitä. Näin Sherlock Holmesin tarinat eli Sherlock-kaanon nähdään autenttisina Watsonin tekeminä muistiinpanoina heidän seikkailuistaan 
Tanja Sihvonen ja Meniina Wik: Uuden Sherlockin uudenlaiset fanit

(Polasek 2012, 42, 43), ja fanit saattavat paneutua esimerkiksi kirjoissa esiintyvien hahmojen "henkilöhistorialliseen" selvitystyöhön. Koska tämä kirjallinen perinne on jatkunut Conan Doylen ajoista saakka, on kaikkea siihen liittyvää aineistoa mahdotonta paikantaa. Osa siihen liittyvistä artikkeleista on kuitenkin onnistuttu kokoamaan kahteen laajaan niteeseen (The Grand Game: A Celebration of Sherlockian Scholarship 2011), joista ensimmäinen sisältää tekstejä vuosilta 1902-1959 ja toinen vuosilta 1960-2010. (The Baker Street Journal 2017.) The Grand Game -perinteeseen osallistuessaan ja fanifiktiota luodessaan Sherlock Holmesin ihailijat kirjoittavat todeksi rakastamiaan kuvitteellisia universumeja. Samalla se on osoitus siitä, että vaikka kirjailija päättäisi lopettaa suositun kirjasarjan tuottamisen, eivät siinä esiintyvät hahmot kuole, vaan he jatkavat elämäänsä uusissa muodoissa (Hoilman 2012). Kaanonin ja faanonin välille ei tässä mielessä voidakaan vetää tiukkaa rajaa.

Uuden Sherlockin viehätys piilee suurelta osin sen intertekstuaalisten viitteiden runsaudessa. Tässä mielessä tv-sarjan käsikirjoittaminen ja tuottaminen on ollut tietoista asettautumista kanoniseen ja fanoniseen kenttään, mikä on vaatinut sarjan tekijöiltä, Mark Gatissilta ja Steven Moffatilta, erityistä ajatustyötä ja kulttuurista lukutaitoa. Uusi Sherlock on esimerkki mediatekstistä, joka operoi transmediaalisessa maisemassa hyödyntäen Holmes-universumin eri säikeitä ja samalla laajentaen sitä uusiin suuntiin. Henry Jenkins $(2008,95)$ määrittelee transmediaalisen tarinankerronnan yhden ja saman tarinamaailman haarautumisena useille eri media-alustoille. Tällöin faneista tulee sekä metsästäjiä että keräilijöitä, kun he toimintansa kautta pyydystävät tarinan kerronnallisia rakenteita ja yhdistävät niiden säikeitä osaksi isompaa kokonaisuutta (Jenkins 2008, 129).

Transmediaalinen tarinankerronta laajentaa fiktiivistä universumia sen sijaan että se tyytyisi vain toistamaan samaa sisältöä yhdestä mediamuodosta toiseen (Harvey 2012, 120). Uusi Sherlock tarjoaa tv-sarjan lisäksi useita alustoja, jotka toimivat sarjan laajennuksina. Totuttuun tapaan Watson toimii US-fiktiossa katsojan tulkkina tehden Holmesia yleisölle ymmärrettäväksi, vaikkakin modernisti blogin kautta. Blogi on löydettävissä internetistä nimellä The Personal Blog of Dr. John H. Watson (www.johnwatsonblog.co.uk), ja Watsonin blogimerkintöjen lisäksi muutkin US:sta tutut hahmot pääsevät siinä ääneen kommenttikentän puolella. US:n henkilöt kirjoittavat blogiin minämuodossa eli ikään kuin roolihahmonsa näkökulmasta, eikä tv-tuotannon ääni ole korostetusti esillä. Myös Holmes itse tuottaa sisältöä omaan The Science of Deduction -blogiinsa, jossa hän autenttisen henkilön tapaan kertoo tutkimuksistaan (www.thescienceofdeduction.co.uk). Vaikka sarjan hahmojen blogit ovat ikään kuin tv-yhtiön tilaamia oheistuotteita, ne voidaan tietyin edellytyksin hyväksyä Sherlock Holmesia käsittelevään fanoniseen kenttään.

Sherlock Holmes -hahmon seikkailuista kumpuaville mediatuotteille näyttää edelleen olevan tilausta ja valmis, erilaisista fanikerrostumista muodostuva katsojakunta. Holmes-universumiin kuuluu lukuisia eri adaptaatioita, joista esimerkkeinä mainittakoon alkuperäistekstille uskolliset, Basil Rathbonen tähdittämät 1930-luvun elokuvat, 2000-luvulla valmistuneet, toimintasankari-Holmesin esitelleet elokuvat sekä televisiosarjat Holmes NYC (Elementary, 2012-) ja tutkimuskohteemme Uusi Sherlock (2010-). Oli tulokulma aiheeseen mikä tahansa, mediatuotteen julkaisija 
voi luottaa valmiin katsojakunnan ja faniyleisön olemassaoloon. Kimurantimpi kysymys kuitenkin on, miten näiden faniyhteisöjen kriittisen katseen kestäviä mediatuotteita luodaan yhä muuttuvassa digitaalisten tietopankkien, jatkuvasti täydentyvien arkistojen ja hakukoneiden määrittämässä maailmassa. Lisäksi fanikulttuurisesta näkökulmasta katsoen on merkittävää, miten tiettyjä alkuperäistekstien piirteitä tuodaan osaksi nykyaikaista transmediatuotantoa. Koska tv-sarjat kuvaavat ihmistä aina sosiaalisena olentona, olennaiseksi kysymykseksi nousee erityisesti se, miten Sherlock Holmes hahmona toimii ihmissuhteiden kentällä. Koska US on niin tietoisesti rakennettu transmediatuotteeksi, täytyy tv-sarjassa kuvattujen ihmissuhteiden toimia inspiraation lähteenä myös eri suuntiin haarautuville fanituotannoille.

\section{Sherlockin Ja Watsonin VÄLINEN SUHDe fanituotannon INNOITTAJANA}

Liikuttaessa Holmes-universumissa kanonisten ja fanonisten tekstien seassa yksi teema nousee ylitse muiden - Holmesin ja Watsonin välinen suhde ja ennen kaikkea sen laatu. Onko kyse romanssista vai vankasta toverillisesta ystävyydestä? Kysymys ei kytkeydy vain ja ainoastaan Uuteen Sherlockiin, vaan sen kanssa on leikitelty useissa muissakin Holmes-mediateksteissä. Suhteen laadun yksityiskohtainen pohtiminen on kuitenkin noussut näkyvämmin esiin fandomissa vasta viime vuosikymmenien aikana, sillä alkuperäisten tarinoiden ilmestymisajankohtana samaa sukupuolta olevien henkilöiden intiimiä suhdetta ei olisi voinut avoimesti käsitellä. Pitkälle 1900-luvulle asti homoseksuaalisuutta pidettiin sekä juridisesti että sosiaalisesti rangaistavana. (Jensen 2014, 7; Caro Lancho 2013, 6.)

Ilmestyessään Conan Doylen Holmes-tarinat edustivat niin sanottua male quest romance -genreä, jossa miespuoliset päähenkilöt asettavat seikkailun seesteisen avioelämän ja muiden yhteiskunnan taholta tulevien velvoitteiden edelle. Tällä vuosituhannella samaa ilmiötä on kutsuttu nimellä bromance, joka kuvaa kahden miespuolisen henkilön välistä läheistä mutta platonista suhdetta. (Bjørklund 2014, 7.) Uuden Sherlockin kohdalla termi ei kuitenkaan ole osuva, sillä lähes jokaisessa tv-sarjan jaksossa Sherlockin ja Watsonin välisen suhteen laatu kyseenalaistetaan sen sijaan, että se nähtäisiin vakiintuneena, keskinäiseen luottamukseen ja henkiseen yhteyteen perustuvana vahvana ystävyytenä (Caro Lancho 2013, 12).

Uusi Sherlock on ensimmäisestä tuotantokaudestaan lähtien leikitellyt perinteistä, dikotomista sukupuolijärjestelmää kyseenalaistavilla queer-viittauksilla ja tukenut samalla sarjan merkittävintä fanituotantoon kannustavaa subtekstiä. Lähes jokaisessa tv-sarjan jaksossa joku esimerkiksi erehtyy luulemaan Holmesin ja Watsonin suhdetta romanttiseksi, ja vaikka tämä tarinan tasolla aina kielletäänkin, saadaan sen kautta myös pidettyä queer-näkökulmaa esillä. Fanitulkintoihin yllyttävää mutta samalla niitä hillitsevää linjaa edustavat sarjan tuottajilta tulevat lausunnot, joissa vakuutetaan Sherlockin ja Watsonin välisen suhteen olevan puhtaasti ystävyyteen perustuva. Koska US kuitenkin leikittelee queer-vihjeillä, sitä on syytetty queerbaitingista eli vähemmistöyleisöjen houkuttelusta katteettomilla lupauksilla sarjan päähenkilöiden välisen suhteen romanttisesta ulottuvuudesta (Fathallah 2014, 2). 
Uusi Sherlock on varsin tietoinen herättämistään queer-tulkinnoista. Tämä on nähtävissä jo sarjan pilottijaksossa, kun sosiaalisesti kömpelö etsivä ja sodasta palannut, sekä mieleltään että ruumiiltaan haavoittunut lääkäri tutustuvat yhteisen tuttavan kautta. Molemmat ovat sekä asunnon että asuintoverin tarpeessa ja niinpä he päätyvät yhdessä Baker Streetille vuokra-asunnon näyttöön. Vuokraemäntä rouva Hudson on ensimmäinen, joka epäilee miesten suhteen laatua tiedustellessaan Watsonilta, ovatko erilliset makuuhuoneet todella tarpeen. Samassa jaksossa miehet keskustelevat keskenään henkilökohtaisista asioistaan. Keskustelun lopputuloksena Sherlock luulee Watsonin olevan homoseksuaali, kiittää häntä saamastaan huomiosta ja kertoo itse olevansa naimisissa työnsä kanssa, sen tarkemmin seksuaalisuuttaan määrittelemättä. (S1E1.)

Slash eli kahden samaa sukupuolta olevan henkilön, tavallisesti miesten, välisen romanttisen suhteen rakentaminen on Uudessa Sherlockissa noussut yhdeksi suureksi sarjan suosiota selittäväksi teemaksi. Nimitys on syntynyt vinoviivasta, jolla inmissuhteisiin keskittyneessä fanifiktiossa erotetaan parinmuodostuksen osapuolet (ks. esim. Bury 2005, 2-3). Suosittua on myös jalostaa parien nimistä erilaisia nimiyhdistelmiä, kuten Sherlockista ja Watsonista käytettävä Johnlock. Vaikka slashissa on kyse ennemminkin läheisyyden, romantiikan ja erotiikan tapaisista teemoista, se sekoitetaan usein silkkaan pornografiseen fiktioon, mikä omalta osaltaan rakentaa sen kyseenalaista mainetta (Duffett 2013,172). Slash on yksi yleisimmistä ja samalla ristiriitaisimmista fanifiktion muodoista. Sitä tekeviä ja kuluttavia yhteisöjä on aiemmin pidetty melkeinpä vaarallisina, ja siihen suhtautuminen voi olla varautunutta jopa faniyhteisön itsensä sisällä (ks. Bacon-Smith 1992, 205; Caro Lancho 2013).

Televisiosarjoissa, elokuvissa ja peleissä tai perinteisemmin kirjallisuudessa esitellyt kuvitteelliset hahmot toimivat inspiraation lähteinä fanien niistä esittelemille tulkinnoille, ja mediatuotteista peräisin olevat viitteet painottuvat eri tavoin katsojasta ja hänen tulkintatavastaan riippuen. Slash-fiktion ympärille on myös syntynyt omia kulttuurisia näyttämöitä, joissa median subtekstejä ja suorasukaisempiakin viitteitä pyritään hyödyntämään fanien omien ilmaisukeinojen sallimissa puitteissa. Koska Uusi Sherlock ei suoraan näytä mitään Sherlockin ja Watsonin välisestä suhteesta kertovaa kuvallista materiaalia, ovat fanit luoneet itse tulkintakehyksiä ja konkreettisia uudelleentulkintoja heidän suhteestaan. Sosiaalinen media tarjoaa Johnlockille omistettuja keskusteluryhmiä ja sivustoja runsain mitoin. Esimerkiksi Facebookissa on tällä hetkellä yli 30 aktiivista Johnlock-ryhmää, joissa on tekstien lisäksi tarjolla kuvanmuokkauksella tehtyjä suutelukuvia, romanttisen suhteen hyvin avoimesti esittäviä piirroksia sekä linkkejä paria käsittelevään slash-fanifiktioon. Näyttää ilmeiseltä, että rajoja rikkova Johnlock-tuotanto kiinnostaa ja innottaa US-sarjan faneja yhä uusiin, luoviin ilmaisun tapoihin.

\section{FANIVIDEOT JA AFFEKTIIVISUUS}

Seuraavaksi tarkastelemme Sherlockin kuolemaan liittyviä fanivideoita, internetissä jaettuja gif-kuvatiedostoja, jotka voivat sisältää myös lyhyitä animaatioita, ja näiden jälkeen analysoimme erikseen samaan aihepiiriin liittyviä meemisovituksia. YouTuben kautta tähän tutkimukseen valikoitu otos sisältää viisi fanien tekemää 
videota ja niiden yhteyteen syntyneet keskusteluketjut. Käsittelemme tässä artikkelissa vain sellaisia videoita, jotka havainnollistavat US-sarjan kuvaston eli sarjan kaanonin hyödyntämistä fanituotannossa. Aineistomme valinnassa olemme käyttäneet menetelmänä harkittua satunnaisotantaa (ks. Östman 2015, 46). Hakusanojen Sherlock, Death ja The Reichenbach Fall avulla valitsimme videopalvelu listaamista videoista lähemmän tarkastelun kohteeksi viisi julkisesti nähtävillä olevaa ja Sherlockin kuolema -kehykseen istuvaa videota. Aineistoa kerätessäme hyväksyimme sen, että tällaisten videoiden lisäksi internetissä on vaikeasti hahmotettava määrä Sherlockin lavastettua kuolemaa koskevaa videomateriaalia, ja että kaikkeen tähän on mahdotonta päästä käsiksi. Sherlock-fandom ei sijaitse yhden palvelun tai alustan takana, jolloin sen kaikkea liikehdintää, fanituotanto mukaan lukien, on mahdotonta paikantaa kokonaisuutena. The Reichenbach Fall -jakso (S2E3) sai ensiesityksensä Britanniassa 15.1.2012, ja aineistoon lukeutuvat videot on julkaistu tästä viikon kuluessa. Näin saimme otoksen Sherlockin kuoleman synnyttämistä tuoreista reaktioista ja fanien tavoista purkaa tuntojaan käyttäen videota välineenä. Videot käsittelevät Sherlockin kuolemaa eri tavoin ja tyylein sekä erinäkökulmista, ja fanit avaavat niistä heränneitä reaktioitaan keskusteluketjuissa kommentoiden kuva-aineistoa sekä videon tunnelmaa ja tarinaa. Mukana on esimerkiksi fanivideo (YT2), joka esittää sekä kaanonille että televisiosarjan kuvastolle uskollisen koosteen sarjassa esiintyvistä hahmoista osana Sherlockin kuolemaan liittyviä tapahtumia. Suurimmassa roolissa videolla on luonnollisesti Sherlock, joka näyttäytyy vuorotellen yhdessä laboratoriotyöntekijä Molly Hooperin, James Moriartyn ja John Watsonin kanssa. Kuolema-teema ja videon läpi jatkuva rauhallinen musiikki nivovat kokonaisuuden yhteen. Tässä videossa poikkeuksellista on se, että tunnelmoiva läpileikkaus tapahtumasta ei herätä erityisiä pohdintoja hahmojen välisistä suhteista tai niiden laadusta.

Yleisesti ottaen fanivideoille on tyypillistä, että niissä keskitytään Sherlockin ja Watsonin väliseen suhteeseen. US-sarjan The Reichenbach Fall -jaksossa (S2E3) esitetty Sherlockin kuolema voidaan tulkita Watsonin katseelle rakennetuksi performanssiksi, joka sisältää vahvan slash-vivahteen. Aiemmin kuvaamamme kohtaus liikkuu eteenpäin tavoitteenaan vain yksi päämäärä eli Watsonin - ja hänen silmiensä kautta katsojan - vakuuttaminen siitä, että Sherlock todella teki itsemurhan ja kuoli pudotessaan. Vaikka kohtauksen tapahtumapaikka on julkinen ja silminnäkijöitä näyttäisi olevan runsaasti paikalla, luodaan kerronnan ja kameratyöskentelyn avulla etsivän ja lääkärin välille varsin intiimiä vuorovaikutusta. Leikkaus ja musiikki täydentävät kohtauksen tunnelmaa Sherlockin toimiessa eräänlaisena lohduttajana, joka tyynnyttelee tapahtumia rakennuksen juurelta seuraavaa ja silminnähden kärsivää ystäväänsä.

Sherlockin kuolemaa kuvaava kohtaus Uudessa Sherlockissa on vaikuttava ja affektiivinen, eikä olekaan ihme, että siitä on fanifiktiossa tehty lukuisia muunnelmia. Aineistostamme kolme fanivideota (YT1, YT4, YT5) kuuluvat luokkaan, jossa kuvataan lohduttajan ja kärsijän välistä (hurt-comfort) kommunikaatiota. Tämä lohduttaja/kärsijä -asetelma yhdistetään usein fanifiktion slash-perinteeseen. Aineistossamme tämä viittaussuhde on kuitenkin tulkinnanvarainen, sillä tarkastelemiamme videoita ei ole nimetty suoraan slashiin viittaavaksi esimerkiksi Johnlock-tunnisteella. Videoissa joko kuullaan tai nähdään kirjoitettuna molempien hahmojen 
repliikkejä, joiden tunnelatausta voi tulkita joko vallitsevan tai queer-lukutavan näkökulmasta. Esimerkiksi ensimmäisen videon avauksessa Watson istuu nojatuolissaan surullisena päätään pidellen, ja kuvaan liukuu teksti "I was so alone and I owe you so much." Fanin henkilökohtainen tulkinta Watsonin tunteesta toimii pohjana katsojan omista lähtökohdistaan ja kontekstistaan tekemille jatkotulkinnoille.

Toisin kuin muilta alustoilta ja hakukoneen kautta kerätyssä materiaalissa, ei Sherlockin kuolemaan liittyvässä fanivideo-otannassamme näkynyt juuri lainkaan leikkisyyttä ja faniyhteisöille ominaista huumoria. Vain yksi viidestä tarkastellusta videosta (YT3) on tarkoituksella tehty hulluttelu (crack vid), jonka vakavasta pohjavireestä vapauttavana tekijänä toimii teemaan sopimaton musiikki. Videon alku on editoitu kohtauksesta, jossa Sherlock seisoo katon reunalla valmiina heittäytymään alas. Hän on soittamassa viimeistä puheluaan Watsonille, ja laskettuaan kännykän käsistään hän heittäytyy alas reunalta kauhistuneen Watsonin seuratessa tapahtumaa alhaalta. Tässä kohtaa musiikki vaihtuu 1990-luvun menestysartisti R. Kellyn I Believe I Can Fly -popkappaleeseen, jonka kertosäkeen sanoitukset korostavat videossa nähtävää hyppyä. Musiikin uudelleenmiksaaminen aiheutti videota kommentoineissa faneissa ääripäiden reaktioita: osa kertoi hulluttelun onnistuneen täydellisesti ja osa pahoitti videosta mielensä kokien sen sopimattomana. Fandomin leikkisän puolen vähäiselle näyttäytymiselle videoaineistossa voi tunnustella selitystä otoksemme julkaisuajasta: fanien sydämet ovat vielä vereslihalla rakastamansa hahmon kuoleman johdosta. Jos videoita keräisi laajemmalta aikaväliltä, leikittelevät fanit olisivat todennäköisesti paremmin edustettuina. Leikillisyyttä ja huumoria käyttäviä esimerkkejä havainnollistamme muilta alustoilta keräämämme aineiston avulla.

Aineistomme perusteella näyttää siltä, että videoissa lohduttajan ja kärsijän välistä dynamiikkaa työstetään tiiviisti The Reichenbach Fall - jakson alkuasetelmasta ja Watsonin roolista käsin. Kussakin tarkastelemassamme videossa Watson esitetään kärsijänä, joka jää Sherlockin kuollessa yksin. Sherlock toimii lohduttajana, joka viimeisen puhelinkeskustelun aikana puhuu Watsonille rauhoittavasti ja kertoo puhelun toimivan ikään kuin viestinä, jonka itsemurhan tehneet tavallisesti jättävät jälkeensä. Videoissa kuvatut tunnelataukset ovat niin voimakkaita, että kärsijäpositio siirtyy myös katsojalle Watsonin kautta. Katsojalle välittyy erityisesti musiikin ja valikoitujen repliikkien kautta työstetty kipu, ja koska Watson toimii sarjassa ylipäätään katsojan samaistumispintana, on Watsonin tunteeseen mukaan tempautumista vaikea välttää.

Kaikille analysoimillemme videoille on yhteistä, että niiden yhteyteen syntyneissä keskusteluketjuissa korostetaan videoiden katsomisesta syntyneitä tunteita. Tämä on keskeinen syy sille, että kutsumme tätä audiovisuaalista fanituotantoa affektiiviseksi. Affektit viittaavat jonkin ulkoisen syyn ruumiissa aiheuttamaan tilaan tai vaikutukseen sekä sen tuloksena syntyneeseen tunteeseen tai emootioon. Affekti on siis välitön fyysinen kokemus, joka tapahtuu irrallaan sen nimeämisestä tai tulkinnasta (Paasonen 2017). Verkkokeskusteluja voidaan myös analysoida yrityksenä selittää, paikantaa ja jakaa muiden kanssa yksilöllisesti koettuja voimakkaita tuntemuksia (ks. Garde-Hansen \& Gorton 2013). Affekteihin kiinnittyvästä näkökulmasta onkin kiinnostavaa, että yleisin Sherlock-keskusteluissa esiintynyt 
teema liittyi tunteisiin ja sisälsi kehuja siitä, miten voimakkaasti latautunut video oli ja miten tehokkaasti se sai katsojan itkemään. Yhdessä tällaisessa kommentissa todettiin, että kommentoija rakasti videota ja oli katsonut sen jopa satoja kertoja (YT5, 5/281). Edellä mainittu humoristinen fanivideo sai myös kehuja, mutta osa niistä päättyi huudahduksenomaisesti vaatimaan siltä lisää "tunteita" (YT3, 1/243). Kommenteista käy ilmi, että moni näyttää katsovan Sherlockin kuolemaa käsittteleviä fanivideoita elääkseen tapahtuman uudelleen ja kokeakseen sen kerta kerralta entistä voimakkaampana.

Toinen alusta, jolta keräsimme aineistoa, on mikroblogipalvelu Tumblr. Palvelun käyttäjät pystyvät YouTuben tapaan asettamaan julkaisunsa joko julkisiksi tai privaateiksi, esiintymään joko omalla nimellään tai nimimerkin takana. Hakusanamme Sherlock, Death ja The Reichenbach Fall toivat nähtävillemme satunnaisen määrän näihin teemoihin limittyvää materiaalia, josta poimimme harkitun satunnaisotoksen. Vaikka The Reichenbach Fall -jakso ja Sherlockin mahdollinen itsemurha kuohuttivat sarjan katsojia, välittyy palvelusta valikoidusta aineistosta myös fandomin leikkisämpi puoli. Sherlockin hyppy kuolemaan on toiminut materiaalina sekä riipaisevan surullisille digitaalisille tuotannoille että hupaisille pienimuotoisille animaatioille. Niissä etsivä alas hypättyään esimerkiksi pelastautuu heliumpallojen avulla (T7) (ks. kuva 2), nousee takaisin katolle toisena brittiläisen populaarikulttuurin suosikkihahmona, Dr. Who'na (T3), tai lentää kuin lintu horisonttiin (T1).

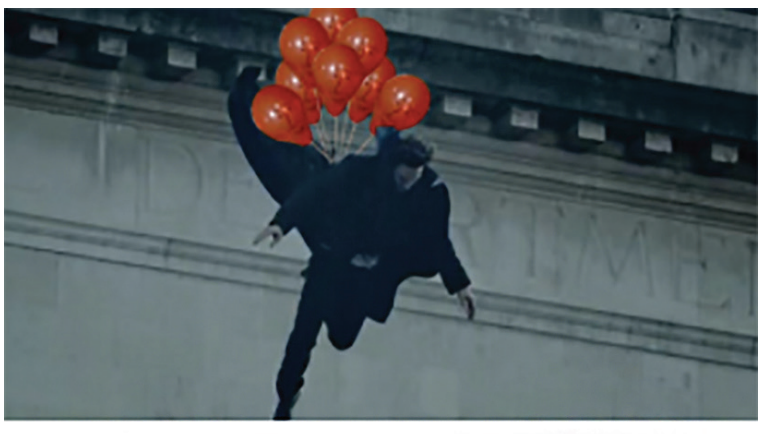

Yksinkertaisille internetissä liikkuville gif-animaatioille tyypilliseen tapaan jakson teemaa on sovellettu myös itse Sherlock-sarjan ulkopuoliseen kuvastoon. Tästä esimerkiksi on valittu viraalivideosta muokattu tiedosto kissasta (T5), joka hyppää alas kaiteelta pyrkiessään viereisen rakennuksen kaiteelle. Kissalle on jälkeenpäin muokattu sininen huivi,

Confirmed, how Sherlock survived his fall. Thanks John Sherlockiin liittyvä merkki, ja se yhdistettynä "Goodbye, John" -lauseeseen niveltää viraalivideon Sherlock-universumiin.

\# bbc sherlock \# benedict cumberbatch

The Reichenbach Fall -jakson tematiikka

83 notes

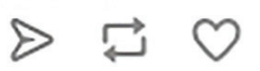
ja tapahtumat puhuttelevat fandomia edelleen, vaikka jakson julkaisusta on

Kuva 2. Sherlock pelastautuu kuolemalta heliumpallojen avulla. jo useita vuosia. Tämä näkyy aineistossamme esimerkiksi tuoreessa fanituotannossa, jossa Sherlock seisoessaan katon laidalla valmiina hyppäämään pitelee kädessään älypuhelinta, ja näytöllä videopuhelussa näkyy John Watsonin lisäksi Pokémon-tuotesarjasta tuttu Pikachu-hahmo (T9) (ks. kuva 3). Vaikuttaako fani siis vihjaavan, että Sherlock saattaisi kuolemansa hetkellä pelata Pokémon Go -peliä? Ehkä kyse on pikemminkin siitä, että ajankohtaisten mediailmiöiden osin sattumanvarainen rinnastaminen ja yhteen sitominen on internet-kulttuurista tuttu keino herättää käyttäjissä tunnereaktioita ja varmistaa siten sisällön "tarttuminen" ja eteenpäin leviäminen. Esimerkiksi Sara 
Ahmed (2004) puhuu juuri merkkien ja representaatioiden liikkeestä ja kierrätyksestä, joiden seurauksena tunnereaktiot syntyvät ja joiden perusteella ne ovat yhteisöllisesti jaettavissa. Samalla kun huolestuneen Watsonin kuvan katsomista voi tarkastella liikuttavana, affektiivisena kohtaamisena katsovan ja katsottavana olevan kehon välillä (esim. Kyrölä 2010, 17), kuvaan liitetty piirroshahmo tuo mukaan koomisen ja vapauttavan elementin, ja tästä ristiriidasta syntyy kuva jonka jakaminen on paitsi vaivatonta myös emotionaalisesti palkitsevaa.

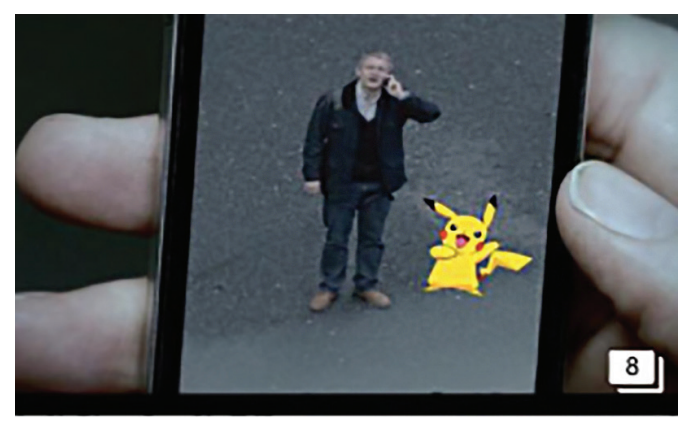

idk who made this but god bless their soul

\# sherlock \# pokemon go \# pokemon

643 notes

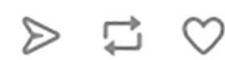

Kuva 3. Sherlock ja Pokémon Go -peli.

\section{UUSi Sherlock meEmien inNoittajana}

Kymmenen vuotta sitten tyypillinen esimerkki teknologian avulla välittyvästä kansanperinteestä oli sähköpostitse lähetetty humoristinen kuva tai ketjukirje. Tänä päivänä samaa edustaa meemi, jonka merkitys vaihtelee kontekstista toiseen. Internet-toimijoiden näkökulmasta meemillä voidaan viitata muun muassa kuvankäsittelyn avulla muokattuun kuvastoon, videoklippeihin, vitseihin, ilmauksiin, ilmeisiin ja sanontoihin, jotka ovat saavuttaneet sekä laajan levikin että suuren suosion. (Heimo \& Koski 2014, 5-6.) Meemit liittyvät myös fanituotantoon ja erityisesti sen jatkuvasti uudelleen muotoutuvaan muotoon. Vaikka meemit voivat myös olla gif- tai videomuotoisia, niiden ilmenemismuoto on usein yksinkertaisempi: niiden perustavin ominaisuus on yhden oivalluksen tai "pointin" mahdollisimman tehokas leviäminen. Ne ovatkin usein affektiivisia eli ne herättävät katsojissaan välittömiä, fyysisiä tunnereaktioita, jotka kannustavat niiden kohtaajia jakamaan niitä eteenpäin.

DeviantArt -palvelu rakentuu käyttäjien oman tuotannon varaan, ja sen kautta jaetaan useita erilaisia taidemuotoja aina digitaalisista tuotteista perinteiseen kirjallisuuteen. Sinne ladattuja kuvia pääsee tarkastelemaan ilman sisäänkirjautumista. Palvelun sisällöstä valikoimme aineistoomme I Believe in Sherlock -meemiin kytkeytyviä fanituotantoja, ja aiemman aineistonkeruumme tapaan teimme tässäkin harkitun satunnaisotannan. Käytimme meemin nimitystä hakulausekkeena, jonka antamista tuloksista valitsimme aineistoomme viisi meemiä. I Believe in Sherlock on yhden fanin ideoima ja sosiaalisessa mediassa suuren suosion saanut liike, jonka avulla osoitetaan tukea The Reichenbach Fall -jaksossa median riepottelemalle Sherlockille. Jaksossa luottamuspulasta kärsivä sarjan päähenkilö kohtaa syytöksiä valheellisuudesta, kuvitteellisten vihollisten luomisesta sekä tutkimiensa tapausten lavastamisesta ja peukaloinnista. I Believe in Sherlock -meemiin osallistujat rakentavat siltaa fiktiivisen Holmes-universumin ja reaalimaailman välille: he ikään kuin puolustavat sankariaan valheellisilta syytöksiltä käyttämällä meemin nimeä näkemystensä julistuksena paitsi tv-sarjan kuvaamassa ympäristössä myös omassa arkielämässään. I Believe in Sherlock -meemi ja sen tuominen osaksi 
reaalimaailmaa kytkeytyvät The Grand Game -perinteeseen, jonka toiminnallisuuden kautta fanit rakentavat Holmes-universumia todeksi (Hoilman 2012).

I Believe in Sherlock -meemin monimuotoisuutta kuvaa hyvin se, että sloganilla varustettuja muistilappuja, spray-maaliviestejä ja t-paitaprinttejä ilmestyi The Reichenbach Fall -jakson esittämisen jälkeen katukuvaan erityisesti Britanniassa, mutta myös muualla maailmassa. Liikkeen slogan ja sen näkyminen niin digitaalisessa kuin reaalimaailmassa vaatii tulkintakontekstikseen sekä Sherlock-ilmiön että fandomin toiminnan tuntemusta. Ilman kontekstuaalista ymmärrystä meemi todennäköisesti näyttäytyi vain yksittäisinä tuotteina muiden fanituotteiden ja -tuotantojen joukossa tai spraymaalitöhryinä rakennusten seinillä. Meemin ilmentämää liikettä voi luonnehtia myös ARG-peliksi (alternate reality game), jonka avulla fanit kokeilivat millaista olisi olla Sherlock-fani US-sarjassa. Fanit siis ikään kuin loivat keinon osallistaa itsensä sarjan universumiin (ks. Boström 2013).

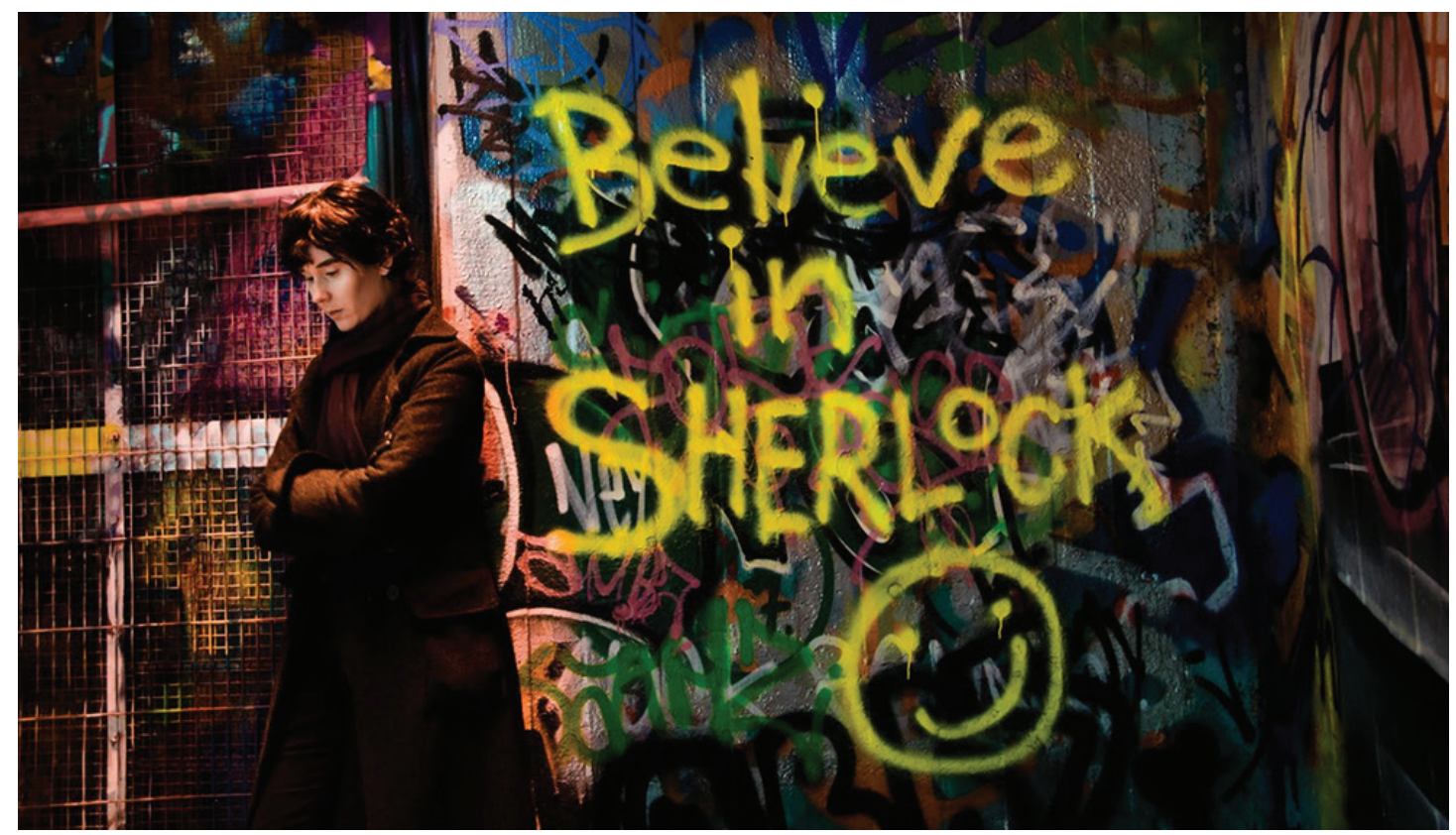

Kuva 4. I Believe in Sherlock -meemi valokuvattuna, toteutusmuotona cosplay (D2).

I Believe in Sherlock -meemin otanta tässä yhteydessä käsittää televisiosarjan kuvastosta digitaalisesti muokattuja teoksia, fanitaidetta (D1, D4, D5) ja cosplayperformanssista otettuja valokuvia (D2, D3). Toiminta kytkeytyy uudella tasolla elämäjulkaisemiseen, jolla viitataan yksityisen henkilön omaelämäkerralliseen toimintaan osana digitaalista kulttuuria (Östman 2015, 15). Niiden merkitys rakentuu myös sen kautta, miten ne on tuotu osaksi lokaatioitaan ja samalla US-universumia. Esimerkiksi cosplay-perfomanssiin ei liity ainoastaan Sherlockiksi tai toiseksi sarjan henkilöhahmoksi pukeutuminen, vaan siihen on kytketty myös meemin slogan esimerkiksi maalattuna spray-värillä rakennuksen seinään (D2, D3) (kuva 4). Performanssista otetaan valokuva, jossa hahmoksi pukeutunut tai tätä muuten esittävä fani poseeraa kameralle yhdessä taustalla olevan sloganin kanssa. Tämän valokuvan julkaiseminen on elämäjulkaisijuutta Sherlock-hahmon näkökulmasta, ja tuo fiktiivisen hahmon mielenkiintoisella tavalla osaksi vuorovaikutteisia digitaalisia 
yhteisöjä. Fanitaidetta on myös tuotu todellisiin paikkoihin ja tilanteisiin esimerkiksi tulostamalla tuotannosta juliste, joka on kiinnitetty kirjaston ilmoitustaululle. Tästä otettu valokuva on taas jaettu DeviantArt -sivustolla fanien kommentoidessa innokkaasti muita todellisessa ympäristössä näkemiään I Believe in Sherlock -meemin muotoja. Meemi kytkeytyy The Reichenbach Fall -jaksossa esitettyihin tapahtumiin vakavalla otteella jättäen fanien keskuudessa viljellyn huumorin vähäiseen rooliin.

Sherlock-sarjaan liittyviä meemejä on liikkeellä useita muitakin, ja saadaksemme yleiskäsityksen näistä etsimme aineistoa myös Google-hakukoneen kautta. Käytettyjä hakusanoja olivat meme, Sherlock, Death ja The Reichenbach Fall. Hakukoneen antamista kuvahaun tuloksista valitsimme toisistaan poikkeavia meemejä, joita vertasimme knowyourmeme.com-sivuston meemikirjastoon etsien vastaavuuksia aineistomme Sherlock-meemisovituksille. Verrattuna aineiston keräämiseen valikoiduilta alustoilta saimme tällä menettelyllä optimoidun katsauksen suosittuihin ja yleisesti tunnettuihin meemeihin, jotka toistavat Sherlock-teemaa.

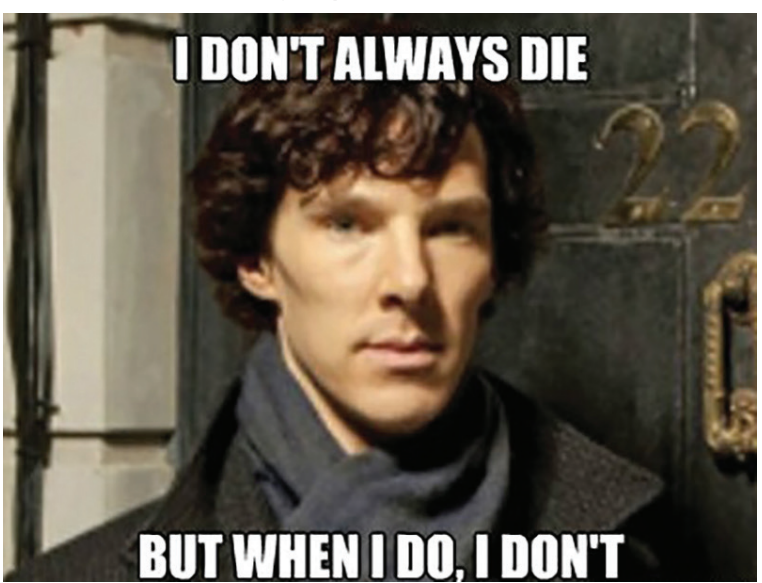

Kuva 5. The Most Interesting Man in the World -meemin Sherlock-sovitus.

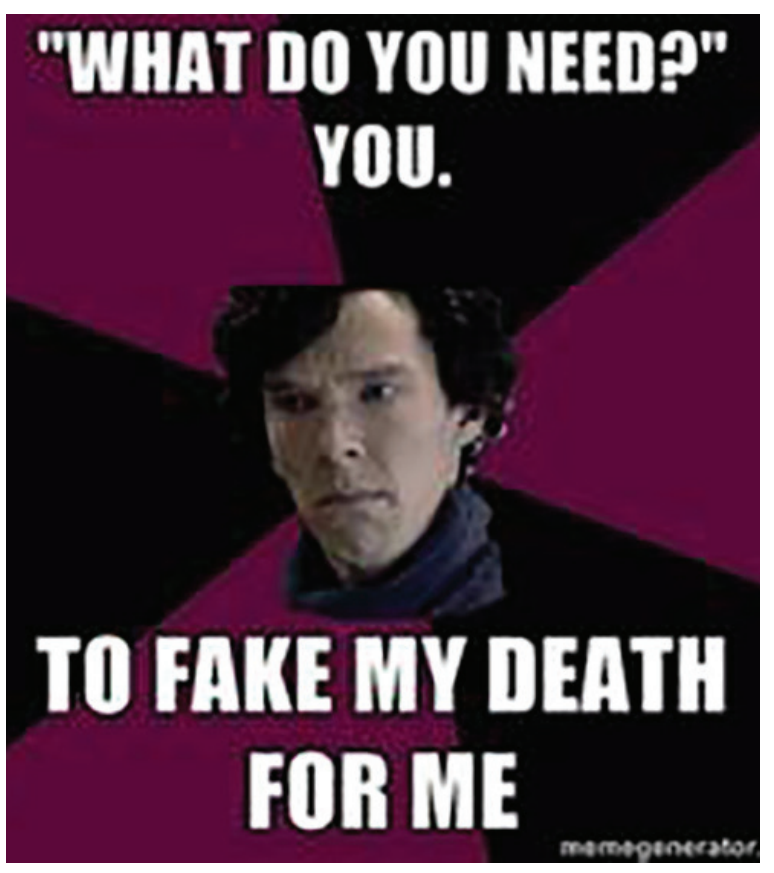

Tässä yhteydessä käsittelemme viittä esimerkkiä, jotka ovat julkisesti nähtävillä.

Aineistossamme on muun muassa alkuperäisestä visuaalisesta ilmeestään tehty muunnelma, jolla on tekstisisältönsä puolesta yhteys esikuvaansa. I don't always die but when I do, I don't -tekstillä varustetussa meemissä on pohjana kuva kameraan katsovasta Sherlockista (ks. kuva 5, G3). Meemin esikuva on The Most Interesting Man in the World -meemi, jolle tunnusomaista on I don't always -alkuinen teksti ja kuvankaappaus yhdysvaltalaisen olutmerkin mainoksessa esiintyvästä miespuolisesta näyttelijästä. Sherlockin ja meemissä tyypillisesti esiintyvän miehen asennossa ja ilmeessä on riittävästi yhteistä, jotta meemikenttää tuntevat näkevät yhteyden alkuperäiseen versioon.

Sherlockin kasvokuvaa on käytetty myös Sexually Oblivious Sherlock -meemissä (ks. kuva 6, G4). Siinä Sherlock tulee sanoneeksi jotain monitulkintaista ymmärtämättä sanomansa kaksimielisyyttä. Meemikuvan ylälaidassa toinen osapuoli esittää kysymyksen "What do you need", johon Sherlockin vastaukseksi

\section{Kuva 6. Sexually Oblivious Sherlock} -meemi, kuolemateemasta toteutettu sovitus. 
Tanja Sihvonen ja Meniina Wik: Uuden Sherlockin uudenlaiset fanit

on kirjattu "You". Tämä vastaus kumotaan kuitenkin kuvan alareunaan lisätyllä

"To fake my death for me" -toteamuksella.

Eri mediatekstien pohjalta kumpuavien meemien yhdistäminen toisiin mediateksteihin on nykyiselle mediamaisemalle tyypillistä, ja aineistostamme löytyy kaksi tällaista meemiä (kuva 7). Näistä ensimmäisessä (G5) sovelletaan Lord of the Rings: The Fellowship of the Ring -elokuvassa esiintyvää kohtausta, jossa Boromir-hahmo kummastelee ajatusta viedä sormusten sormus tuhottavaksi Mordoriin, tarinan fiktiiviseen pahuuden tyyssijaan. Hän pukee inmetyksensä toteamukseksi "One does not simply walk into Mordor". Tästä lähti 2000-luvun alussa liikkeelle meemi, jossa verbi walk korvattiin jollain toisella ja myöhemmin myös lokaatio Mordor vaihtui. Sherlock-teemaan meemi on sovitettu yhdistämällä alkuperäinen kuvakaappaus painokkaasti toteavasti Boromir-hahmosta tekstiin One does not simply not cry at the end of the Reichenbach Fall.

Toinen aineiston mediatekstimix on animaatiosarja Paavo Pesusienen nimihahmoon perustuva Tough Sponge Bob-meemi (G6). Se on lähtenyt liikkeelle sarjan jaksosta, jossa Paavo Pesusieni (optimistinen merenalaisessa kaupungissa asuva sienieläin) yrittää päästä kovien tyyppien kerhoon. Päästäkseen sisään hän selittää paikan portsarille, että telottuaan taannoin varpaansa hän itki ainoastaan 20 minuuttia. Tästä kohtauksesta muotoutuneessa meemissä Paavo Pesusieni esittää itsevarman välinpitämätön ilme kasvoillaan erilaisia tilanteita, joiden vuoksi itki vain 20 minuuttia. Sherlock-fanit ovat soveltaneet meemiä muuttaen Pesusienen sanomaksi merkityn tekstin muotoon "I'll have you know that I only cried for 3 days after the Reichenbach Fall". Tätä ja Lord of the Rings -mediatekstistä muotoutunutta meemiä yhdistää se, että niissä käytetyt kuvat pysyvät samoina tekstin vaihtuessa meemejä käyttävien mediatekstien ja teemojen mukaan.
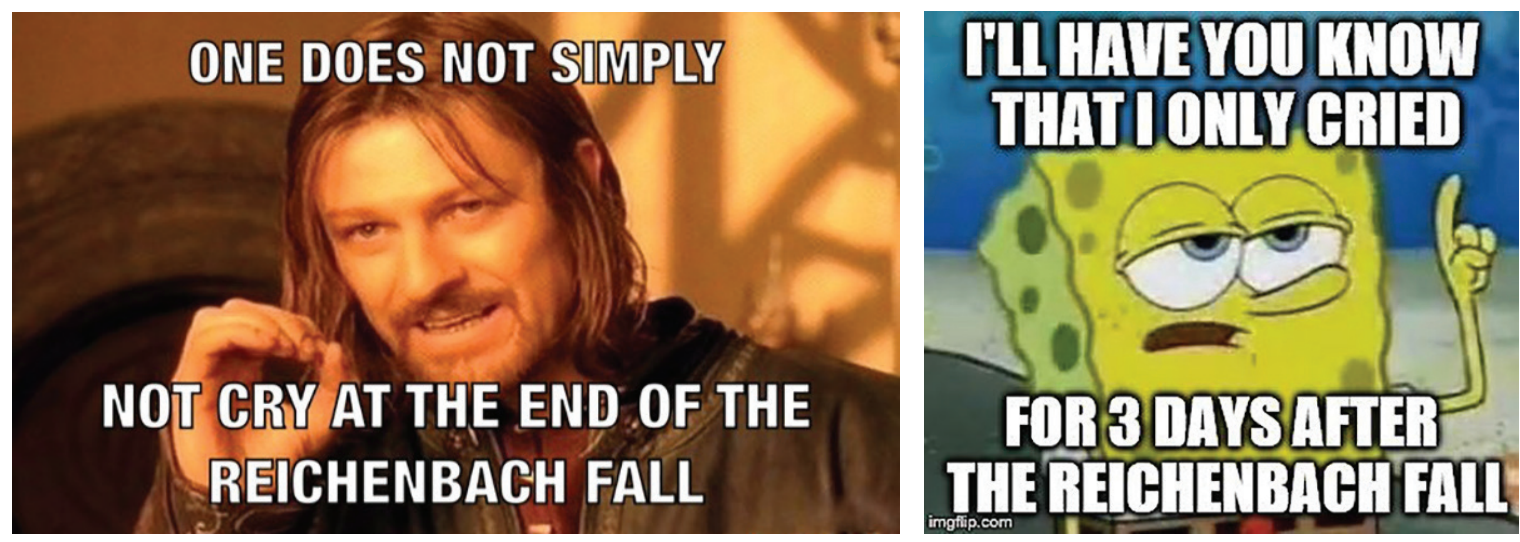

Kuva 7. One does not simply - ja Tough Sponge Bob-meemien Sherlock-sovitukset.

E-kortti on meemi, jossa valittavana on tyypillisesti mustavalkopiirroskuva yksinkertaisella väripohjalla. Myös nämä meemit rakentavat kytköksen viittauskohteeseensa kuvan sijaan tekstin kautta. Aineistoesimerkkeihin valikoituneessa meemissä on laventelinvärinen pohja ja sen oikeassa reunassa piirretty naishahmo istumassa sängyllä peittäen silmänsä kädellään (Kuva 8, G7). Tekstinä on "Watch Sherlock, they said. $I(t)$ will be fun, they said. Watch "The Reichenbach Fall" they 
said, it will be fun, they said". Naishahmo kuvastaa siis turtuneen katsojan surua siitä, miten hänen odotuksensa Uuden Sherlockin suhteen murskautuivat erityisesti The Reichenbach Fall -jakson katsomisen jälkeen. Tässä, kuten muissakin tässä luvussa analysoimissamme esimerkeissä meemin muokkaaja käyttää yleisesti tunnettua ja tietyn reaktion herättävää memeettistä alustaa ilmaistakseen omaa tunnereaktiotaan tunnistettavalla ja sosiaalisessa mediassa hyväksytyllä tavalla. On todennäköistä, että meemien toimivuus fanituotannon näkökulmasta kytkeytyykin juuri niiden ilmaisullisen potentiaalin monimuotoisuuteen, samalla kun niiden käytännön toteutus on yksinkertaista ja jakaminen varsin helppoa.

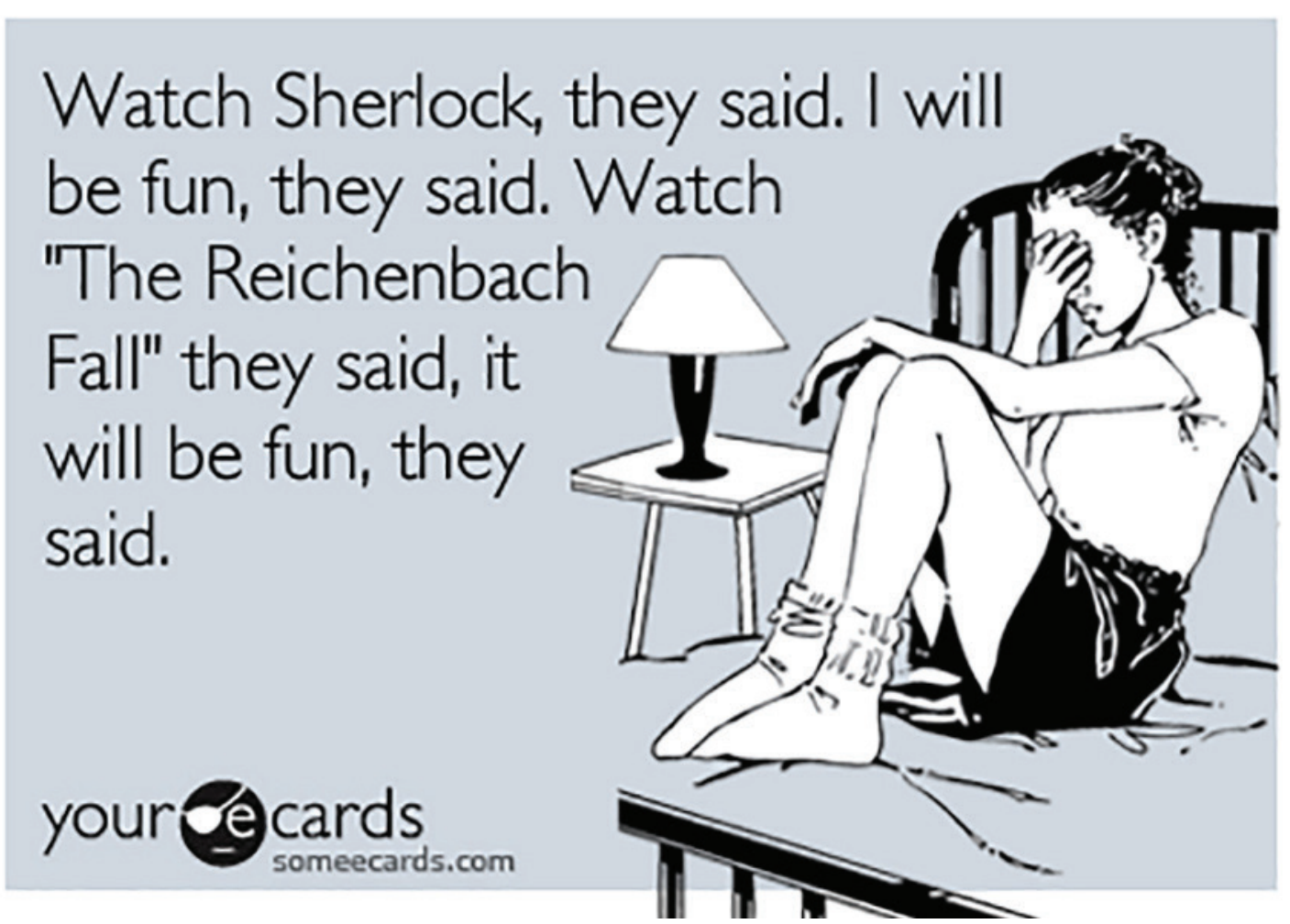

Kuva 8. E-kortti -meemin Sherlock-sovitus.

\section{Fanitulkinnat Sherlockin KUOlemasta JA tUOtanNon NÄKÖKULma}

Uuden Sherlockin toisen tuotantokauden päättävän The Reichenbach Fall -jakson yleisöreaktio ja siitä seurannut kuohunta oli kuin aikamatka kirjallisen Holmes-hahmon kuolemaan 1800-luvun lopulle. Tuolloin fanit kirjoittivat närkästyksestään TitBits -viikkolehteen, kun taas 2010-luvun faniyhteisö purki tuntojaan sosiaalisen median kentällä muun muassa Tumblrissa, Twitterissä, YouTubessa ja Facebookissa. Fanien voimakas reagointi, paheksunta ja protestointi näkyivät myös reaalimaailmaan siirtyneenä I Believe in Sherlock -kampanjan julisteina ja lentolehtisinä. (McLaughlin 2013, 2-3.)

Aineistonkeruuprosessimme aikana huomasimme, että Sherlockin kuolema oli irtautunut fanien käsissä sarjan alkuperäisestä tarinarakenteesta. Vaikka kuolemaa kuvaavan jakson (S2E3) lopussa Sherlockin hahmo vilahtaa ruudussa, katsojat eivät 
ole voineet ennen kolmannen kauden alkua (1.1.2014) tietää, miten Sherlockin on ollut mahdollista selvitä hypystä hengissä. Uuden Sherlockin toisen ja kolmannen tuotantokauden väliseen kahteen vuoteen mahtuikin runsaasti The Reichenbach Fall -jakson tapahtumien ja henkilöiden välisten suhteiden uudelleentulkintaa. Erilaisten tulkintojen sekä niiden pohjalta tehtyjen fanituotantojen määrä osoittautui laajaksi, ja ne hyödynsivät sosiaalisen median ilmaisu- ja levitysmuotoja monin kekseliäin tavoin.

Kun US:n kolmas tuotantokausi käynnistyi tammikuussa 2014, huomasivat katsojat jo ensimmäisen jakson perusteella sarjan tuotannon todennäköisesti seuranneen fandomin liikehdintää ja myös reagoineen heidän esittämiinsä teorioihin. Tässä The Empty Hearse -nimisessä (suom. Tyhjä ruumisauto) jaksossa esitetään heti kärkeen kohtaus hyppäävästä Sherlockista. Tämä kohtaus rakentuu ikään kuin tuotannon vastauksena fanien internetissä esittämiin fantasioihin, jotka liittyvät sekä Sherlockin pelastumiseen kuolemalta että tämän romanttisten tunteiden kohteeseen. Jaksossa Sherlock toimintasankarin elkein selviää hypystä vyötärölleen kiinnitetyn elastisen köyden avulla, joka ponnauttaa hänet takaisin ylös juuri ennen asfalttiin iskeytymistä ja sinkoaa hänet Bartholomew'n sairaalan ikkunasta läpi lasinsirpaleiden halkoessa ilmaa. Ennen pois paikalta kiiruhtamistaan Sherlock ehtii vielä suutelemaan sairaalassa työskentelevää laboratoriotyöntekijä Molly Hooperia. Sherlockin ja Mollyn syvenevän suhteen mahdollisuudesta innostuneet fanit kuitenkin pettyvät kohtauksen leikatessa nopeasti sarjan muihin hahmoihin, rikoskomisario Lestradeen ja hänen apuriinsa, rikosteknikko Andersoniin. Miesten välinen keskustelu paljastaa edellä näytetyn olleen fantasiakohtaus, joka vain kuvitti Andersonin oman version tapahtuneesta.

Anderson, sarjaan sisäänkirjoitettu fanihahmo, representoikin jaksossa usealla tapaa Sherlock-sarjan faneja ja toimii ikään kuin heidän tuotannon nimittämänä edustajanaan US-mediatekstin sisällä. Hän on muun muassa perustanut jakson nimenä toimivan ja sarjan fiktiiviseen maailmaan liittyvän The Empty Hearse -ryhmän, jonka jäsenet esittävät kokoontumisissaan mitä villeimpiä teorioita Sherlockin kuolemasta, sen lavastamisesta sekä tapahtumakulkuun liittyvistä motiiveista (kuva 9). Useita fanien teorioita Sherlockin lavastetusta kuolemasta esitetään jakson kuluessa fantasiakohtausten muodossa. Yksi kuuluisimmista tällaisista kohtauksista on Sherlockin ja Moriartyn välinen suudelma sairaalan katolla molempien lavastettua onnistuneesti itsemurhansa. On mielenkiintoista, että tämäkin fantasiakohtaus leikkautuu jälleen rikosteknikko Andersoniin, joka tyrmää moisen teorian järjettömänä johtamansa faniryhmän jäsenten kuunnellessa vakavina.

Sarjan fiktiiviseen maailmaan lukeutuvat Anderson ja hänen perustamansa The Empty Hearse -ryhmä ovat osa Uuden Sherlockin tarinarakennetta oletettavasti monestakin syystä. Sarjan tuottajien pyrkimystä tuoda faneja osaksi sarjan kerronnallista jatkumoa voidaan tulkita representaatioiden politiikan lähtökohdista: US-sarjassa faneja näyttelevät sekä esittävät varsin stereotyyppisesti käsikirjoitettuja fani-identiteettejä että edustavat mediatekstin sisäisessä maailmassa US-sarjan todellisia faneja ja heidän tulkinnallista työtään. Kuvatussa faniryhmässä on mukana tummiin verhoutunut gootti, Sherlockin deerstalker-hattuun pukeutunut nörtti ja hiljainen silmälasipää. Myös Anderson itse osoittautuu "hysteeriseksi 


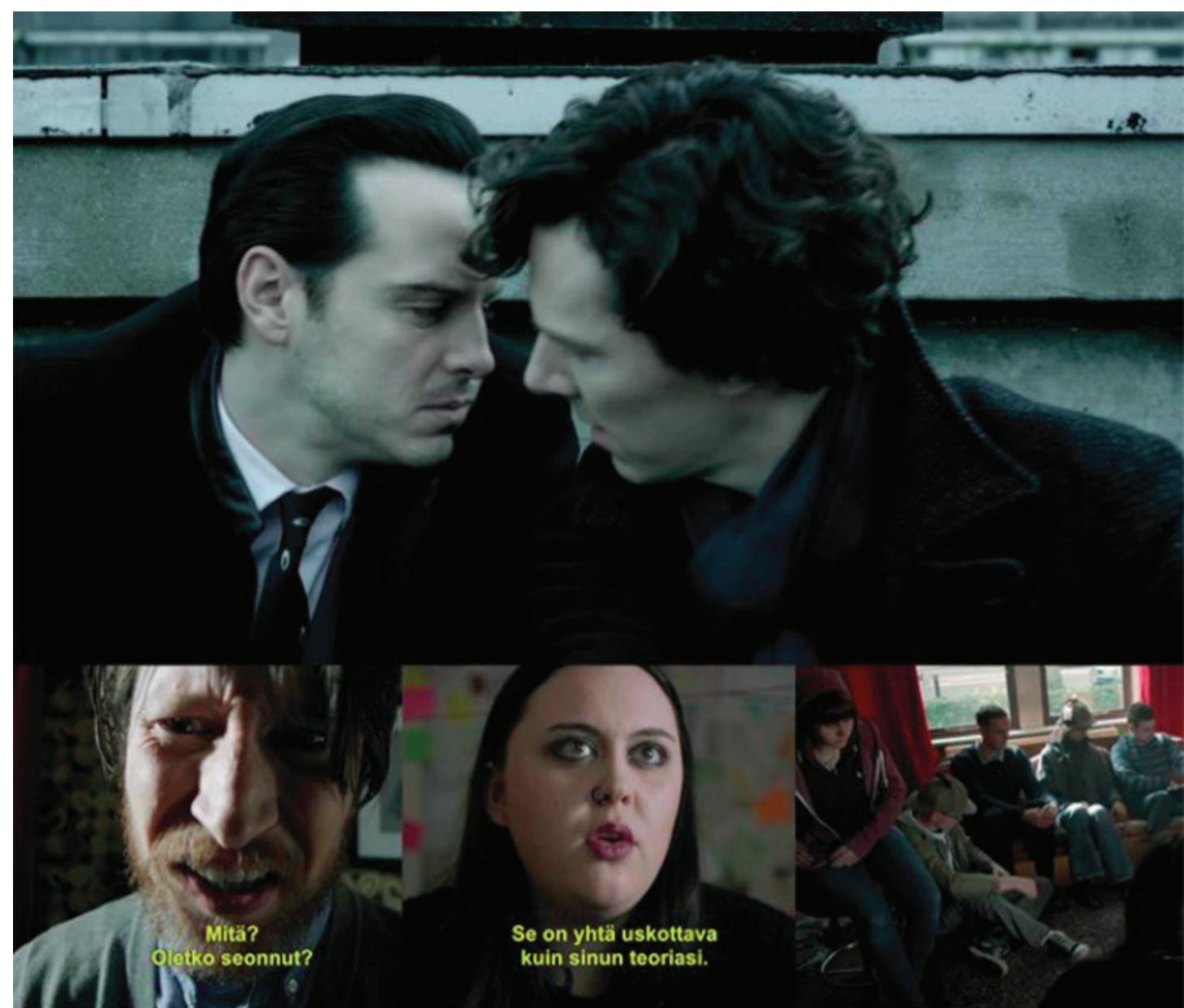

Kuva 9. Slash-fantasiakohtaus ja siihen reagoiminen The Empty Hearse -ryhmän tapaamisessa.

faniksi" viimeistään kohtauksessa, jossa katsoja näkee hänen tapetoineen asuntonsa seinät Sherlockiin liittyvillä lehtileikkeillä. Analyysimme tulosten pohjalta voimme todeta, että US ei uudista fanin representaatiota vaan nojautuu heidän osallistamisestaan huolimatta negatiivisiin ja stereotyyppisiin populaarikulttuurin fanikäsityksiin.

TV-sarjan tuotantokoneiston ja fanituotannon väliset kytkökset toimivat näiden välisellä huokoisella rajapinnalla. US: n tuotannossa hyödynnetään kulttuurista lukutaitoa ja paikannetaan sarjan fanien keskuudessa leviävät kuumimmat puheenaiheet samalla kun sen käsikirjoitus flirttailee sopivasti heidän kanssaan vaarantamatta sarjan suosiota valtayleisön keskuudessa. Esimerkiksi queer-tulkintojen tiedostaminen ja satunnaiset silmäniskut sille riittävät rakentamaan sarjan suosiota menettämättä tätä tulkintatapaa vieroksuvia faneja. Tuotannossa mediatekstiin voidaan myös sisällyttää faneja puhuttelevia sivupolkuja ja täkyjä, kuten aihetunnisteita ja verkko-osoitteita. Faniyhteisöt taas viestivät tuotantoon päin esimerkiksi fanituotannon kautta - se toimii yhteisön erilaisten tulkintakehysten esittelyyn sopivana välineenä, jonka avulla mediatekstin kaupallinen tuotantokoneisto tavoittaa faniyhteisössä liikkuvia teemoja. Reagoimalla fanituotantoon tuotantokoneisto avaa dialogia sarjan tekijöiden ja sen kuluttajien välille. Tämä dialogi ei kuitenkaan aina, 
Tanja Sihvonen ja Meniina Wik: Uuden Sherlockin uudenlaiset fanit

kuten The Empty Hearse -jakso osoittaa, näy mediatekstissä täysin molempia osapuolia kunnioittavalla tavalla.

Vaikka faneja osallistettiin US:n kolmannen kauden ensimmäisen jakson juonikulkuun ja heitä täten puhuteltiin suoremmin kuin aikaisemmin, ei jakso silti tarjoa visuaalista materiaalia sarjan ehkäpä keskeisimmästä fanikulttuurisesta teemasta, Sherlockin ja Watsonin suhteesta. Johnlock-fanit eivät siis saaneet jakson myötä tukea kuvitelmilleen, vaikka niihin oletettavasti liittyisi herkullisia fantasiakohtauksen aineksia. Tähän voi hakea selitystä tuotannon jyrkän suhtautumisen lisäksi siitä, että vihjailut miesten välisen romanttisen suhteen olemassaolosta toimivat sarjan suosiota rakentavana tekijänä. Niin kauan kuin hahmojen välistä jännitettä pidetään yllä, siitä päästään fanien kesken nauttimaan. Fanien innokkuus sekä sarjaa että sen hahmoja kohtaan voisi yksinkertaisesti laskea, jos Sherlockin ja Watsonin romanttinen suhde otettaisiin mukaan kaanoniin. Muun muassa kanonisen Sherlock Holmesin erakkomainen elämäntapa ja hänen omaan seksuaalisuuteensa liittyvästä keskustelusta pidättäytyminen ovat luoneet fanien keskuudessa tarpeen erilaisten romanssien kehittelylle (Faye 2012, 6-7). Jos astutaan mediatekstin hahmokehästä askel taaksepäin, voidaan pohtia, miksi juuri Uusi Sherlock on tv-sarjana herättänyt fanien tutkivan asenteen henkiin. Selitystä voi etsiä kulttistatuksesta, jota kohti Uusi Sherlock on matkalla. Kulttisarjoja yhdistää tapa, jolla ne kutsuvat fanejaan tekemään tutkimustyötä: päättymättömät ja kerroksittaiset tarinarakenteet houkuttelevat faneja tulkitsemaan niitä omalla tavallaan ja luomaan uutta, kaanonin ohittavaa tietoa. (Hastie 2007, 89.) Myös Uusi Sherlock sisältää tällaisia houkuttimia, joista Sherlockin ja Watsonin välinen suhde on mielestämme kiinnostava esimerkki. Täytyy kuitenkin muistaa, että homoeroottinen subteksti on kuitenkin vain yksi tapa kurottaa kaanonin ulkopuolelle, vaikka juuri se usein nostetaankin korostetusti esiin (ks. Hills 2012, 44; Polasek 2012, 53).

\section{LOPUKSI}

Tässä artikkelissa olemme tarkastelleet Uusi Sherlock -sarjan ja Sherlock Holmes -hahmon inspiroimaa fanituotantoa ja osoittaneet, miten US antaa poikkeuksellisella tavalla faneilleen näkyvyyttä tuomalla heihin perustuvia hahmoja osaksi sarjan kerrontaa ja käyttämällä heidän visioitaan tapahtumista sarjassa esiintyvien fantasiakohtausten lähteinä. Fanit on siis otettu mukaan Uuden Sherlockin kerronnallisiin rakenteisiin. US:ssa esiintyvien fanihahmojen puheenvuorot näyttäytyvät sen narratiivissa ikään kuin metatekstinä eli itse tv-sarjan sisältöä kommentoivina huomioina. Tästä huolimatta nämä hahmot nojaavat perinteiseen ja stereotyyppiseen populaarikulttuurin fanikäsitykseen, eikä fanin representaatio sarjan kuvaston myötä uudistu. Uuden Sherlockin kautta avautuva kuva faniudesta ja fanituotannosta on monimuotoisuudessaan ja ristiriitaisuudessaan kiehtova tutkimuksen kohde.

Sherlock Holmes on maailmanlaajuisesti tunnettu hahmo, jota käsitteleville mediatuotannoille on aina olemassa valmis ja aktiivinen yleisö. Näin myös Uusi Sherlock on löytänyt paikkansa Holmes-universumissa, vaikka sarjan tulokulma kanonisoituun lähdemateriaaliinsa on totuttua tuoreempi ja uudistavampi. Sarjan tuotannossa on ymmärretty sen faniyhteisön muodostuvan sulavasti digitaalisessa 
mediamaisemassa ja fanonisten käytäntöjen keskellä liikkuvista toimijoista. Heistä moni osaa ottaa vastaan tuotannon tarjoaman kerronnallisen kädenojennuksen sekä aihetunnisteiden ja muiden täkyjen muodostaman kartan navigoidakseen Sherlock Holmesin ympärille rakentuneessa transmediaympäristössä, jossa tv-sarja näyttäytyy vain yhtenä kiinnekohtana muiden joukossa. Tutkimuksemme mukaan US onkin poikkeuksellisen perinnetietoinen sarja siinä mielessä, että sen tekijät näyttävät olevan hyvin tietoisia Sherlock Holmes -faniuden pitkästä historiasta, joka näkyy muun muassa The Grand Game -tradition jatkumisena.

Uuden Sherlockin ja siihen liittyvän fanituotannon tarkastelu on osoittanut, miten digitaalisella ajalla fanitoiminnan ja -julkaisemisen voidaan sanoa nousseen marginaaleista osaksi valtavirtaa. US:ää tarkasteltaessa on ollut erityisen mielenkiintoista havainnoida, miten monipuolisesti faneja huomioidaan kaupallisessa tuotantokoneistossa. Fanit taas vastaavat heitä puhuttelevaan sisältöön paitsi osallistumalla keskusteluihin internet-forumeilla myös kierrättämällä ja remiksaamalla mediatekstiä tunteisiin vetoaviksi fanituotannoiksi. Aineistossamme näkyy, miten nopeasti ja intohimoisesti fanit reagoivat: analysoimamme YouTube-videot on julkaistu viiden päivän sisällä sarjan toisen tuotantokauden päättävän Loppunäytös-jakson esittämisestä. Olemme tässä artikkelissa kytkeneet nämä nopean fanituotannon syklit Sherlock Holmes -faniuden pitkiin perinteisiin pyrkien osoittamaan, miten faniudessa on aina samaan aikaan sekä uudistavia että säilyttäviä piirteitä. Uutta Sherlockia ja siihen kytkeytyviä faniuden käytäntöjä tutkimalla olemme tässä artikkelissa osoittaneet, miten perinteinen osallistuva fanius voi digitaaliset ilmaisun välineet - videon, gif-tiedostot, kuvameemit ja verkkokeskustelut - haltuun ottamalla muovautua uudessa ympäristössä sulavasti toimivaksi ja affektiivisesti leviäväksi, uudenlaiseksi fanikulttuuriksi. 


\section{TUTKIMUSAINEISTOT}

\section{DeviantART -fanitaidesivustolta kerätty fanituotanto:}

DA1: I Believe in Sherlock Holmes

http://iwan888.deviantart.com/art/I-Believe-in-Sherlock-Holmes-289408486

DA2: Believe in Sherlock

http://shigeako.deviantart.com/art/SHERLOCK-Believe-in-Sherlock-338819159

DA3: Sherlock [BBC - Lestrade]: Believe in

http://www.deviantart.com/art/Sherlock-BBC-Lestrade-Believe-In-307606735

DA4: 'I BELIEVE IN SHERLOCK HOLMES'

http://www.deviantart.com/art/I-BELIEVE-IN-SHERLOCK-HOLMES-285117651

DA5: I Believe in Sherlock Holmes

http://www.deviantart.com/art/I-Believe-in-Sherlock-Holmes-280533713

\section{Google-hakukoneen kautta kerätyt meemit:}

www.google.fi, hakusanat: Sherlock, Death ja The Reichenbach Fall.

G1: Ancient Aliens -meemi

G2: Demotivional Posters

G3: The Most Interesting Man in the World -mukaelma

G4: Sexually Oblivious Sherlock

G5: One does not simply -meemi

G6: Tough Sponge Bob -meemi

G7: E-kortti

\section{Mainitut Uusi Sherlock -tv-sarjan jaksot:}

S1E1: A Study in Pink (2010). Suom. Vaaleanpunainen kuolema. Tuotanto: BBC ja Hartswood Films. Esiintyjät: Benedict Cumberbatch, Martin Freeman.

S2E1: A Scandal in Belgravia (2012). Suom. Kiusallinen skandaali. Tuotanto: BBC ja Hartswood Films. Esiintyjät: Benedict Cumberbatch, Martin Freeman, Lara Pulver.

S2E3: The Reichenbach Fall (2012). Suom. Loppunäytös. Tuotanto: BBC ja Hartswood Films. Esiintyjät: Benedict Cumberbatch, Martin Freeman.

S3E1: The Empty Hearse (2014). Suom. Tyhjä ruumisauto. Tuotanto: BBC ja Hartswood Films. Esiintyjät: Benedict Cumberbatch, Martin Freeman, Amanda Abbington. 
Tanja Sihvonen ja Meniina Wik: Uuden Sherlockin uudenlaiset fanit

[http://www.elore.fi/arkisto/2_17/sihvonen_wik.pdf]

\section{Muu aineisto:}

Ward, Susannah (2014) (ohjaaja) Unlocking Sherlock. Suom. Kulissien takana: Uusi Sherlock. Tv-dokumentti, es. YLE TV2 07.01.2016. Tuotanto: Midnight Oil Productions. Esiintyjät: Benedict Cumberbatch, Mark Gatiss, Steven Moffat, Martin Freeman.

knowyourmeme -meemisivusto Google-hakukoneen kautta kerättyjen meemien taustatietojen lähteenä.

\section{Tumblr-mikroblogipalvelun kautta kerätty fanituotanto:}

\section{https://www.tumblr.com/ (vaatii sisäänkirjautumisen)}

T1: Nimi: i believe i can fly. Vastaukset, tykkäykset ja uudelleenbloggaukset: 97

T2: Nimi: one more miracle... Vastaukset, tykkäykset ja uudelleenbloggaukset: 2 369

T3: Nimi: one of the theories how sherlock could survive. Vastaukset, tykkäykset ja uudelleenbloggaukset: 2954

T4: Nimi: Please don't go, I want you to stay I'm begging you please, please don't leave me. Vastaukset, tykkäykset ja uudelleenbloggaukset: 608

T5: Nimi: I'M LAUGHING WAY TOO MUCH FOR THIS. Vastaukset, tykkäykset ja uudelleenbloggaukset: 532

T6: Nimi: One more miracle, Sherlock, for me. Don't. Be. Dead. Vastaukset, tykkäykset ja uudelleenbloggaukset: 1949

T7: Nimi: Confirmed, how Sherlock survived his fall. Thanks John. Vastaukset, tykkäykset ja uudelleenbloggaukset: 83

T8: Nimi: I did another one. Take this phone away from me. Aihetunnisteet: Vastaukset, tykkäykset ja uudelleenbloggaukset: 83

T9: Nimi: I did another one. Take this phone away from me. Vastaukset, tykkäykset ja uudelleenbloggaukset: 83

T10: Nimi: nimetön. Vastaukset, tykkäykset ja uudelleenbloggaukset: 111

T11: Nimi: I o U. Vastaukset, tykkäykset ja uudelleenbloggaukset: 467

\section{Videopalvelu YouTuben kautta kerätty fanituotanto:}

YT1: Nimi: Sherlock Holmes ^ Death. Kommenttien lukumäärä: 219. Julkaisupäivä: 16.1.2012. https://www.youtube.com/watch?v=0TJ9kKELOfU

YT2: Nimi: Sherlock - Death. Kommenttien lukumäärä: 115. Julkaisupäivä: 18.1.2012. https://www. youtube.com/watch? $v=$ IXBbmU0wQP0

YT3: Nimi: Sherlock Jumps - The Reichenbach Fall. Kommenttien lukumäärä: 243. Julkaisupäivä: 16.1.2012. https://www.youtube.com/watch?v=zI-IULYX3qY

YT4: Nimi: Sherlock BBC - The Final Problem (Better quality). Kommenttien lukumäärä: 105. Julkaisupäivä: 16.1.2012. https://www.youtube.com/ watch?v=cTvuxhKd9vA 
Tanja Sihvonen ja Meniina Wik: Uuden Sherlockin uudenlaiset fanit

[http://www.elore.fi/arkisto/2_17/sihvonen_wik.pdf]

YT5: Nimi: Sherlock BBC | Arrival of the Birds. Kommenttien lukumäärä: 281. Julkaisupäivä: 19.1.2012. https://www.youtube.com/watch?v=sydKCLJDWpQ

\title{
Kuvio 1, KUVALÄHTEeT
}

\author{
http://www.basilrathbone.net/ \\ https://i.pinimg.com/736x/ef/a2/8a/ \\ efa28a623084f19936e3b380b4441409--jeremy-brett- \\ http://hero.wikia.com/wiki/Sherlock Holmes (Robert Downey Jr.) \\ http://www.bbcamerica.com/anglophenia/2017/02/ \\ sherlock-named-the-worlds-most-popular-bbc-character
}

\section{KirJallisuUs}

Aalto, Tuija \& Marylka Yoe Uusisaari 2009: Nettielämää. Sosiaalisen median maailmat. Jyväskylä: BTJ kustannus.

Ahmed, Sara 2004 [online]: Affective Economies. Social Text 22(2): 117-139. <https://muse.jhu.edu/article/55780/pdf> [20.10.2017].

Bacon-Smith, Camille 1992: Enterprising Women: Television Fandom and the Creation of Popular Myth. Philadelphia: University of Pennsylvania Press.

Barnett, Barbara 2007 [online]: Dr. Gregory House: Romantic Hero. <http:// blogcritics.org/video/article/dr-gregory-houseromantic-hero/> [7.12. 2010].

Biography 2016 [online]: swww.arthurconandoyle.com/biography.html> [2.12.2016].

Bjørklund, Miriam 2014: "To face it like a man": Exploring Male Anxiety in Dracula and the Sherlock Holmes Canon. A thesis in English Literature Submitted to the Faculty of Humanities. Department of Literature, Area Studies, and European Languages. Oslo: Universitetet i Oslo.

Bolter, Jay \& Richard Grusin 2000 [online]: Remediation. Understanding new media. Cambridge, MA: The MIT Press. <https://monoskop.org/images/a/ae/ Bolter Jay David Grusin Richard Remediation Understanding New Media low quality.pdf> [2.9.2016]

Boström, Mathias 2013 [online]: Mika Hallor from Sweden started the movement \#believeinsherlock. <http://www.sherlockholmes.se/2012/03/11/mika-hallorfrom-sweden-started-the-movement-believeinsherlock/> [8.5.2017].

Bury, Rhiannon 2005: Cyberspaces of their own. Female fandoms online. New York: Peter Lang.

Caro Lancho, Melissa 2013 [online]: Holmes and Watson or Sherlock and John: A homoerotic reading of Conan Doyle's Characters in BBC's Sherlock. <https:// ddd.uab.cat/pub/tfg/2013/112443/Melissa_Caro.pdf> [18.11.2016].

Coelho, Samantha 2011: The Case Study of Sherlock Holmes 2009: An Ethnographic Investigation into the Systematic Cultivation of a Fan. Auckland: School of Communication Studies. 
Coppa, Francesca 2008 [online]: Women, Star Trek, and the early development of fannish vidding. Transformative Works and Cultures 1. <http://journal. transformativeworks.org/index.php/twc/ article/view/44/64> [30.1.2017].

Deuze, Mark 2007: Convergence Culture in the creative industries. International Journal of Cultural Studies 10(2): 243-263.

Duffett, Mark 2013: Understanding Fandom: An Introduction to the Study of Media Fan Culture. New York: Bloomsbury Academic.

Evans, Adrienne \& Mafalda Stasi 2014: Desperately seeking methodology: New directions in fan studies research. Participations, Journal of Audience \& Reception Studies 11(2): 4-23.

Evans, Elizabeth Jane 2012: Shaping Sherlocks. Institutional Practice and the Adaption of Character. - Stein, Louisa Ellen \& Kristina Busse (eds.), Sherlock and Transmedia Fandom. Essays on the BBC series. Jefferson, NC: McFarland. 102-117.

Fathallah, Judith 2014: Moriarty's Ghost: Or the Queer Disruption of the BBC's Sherlock. Television \& New Media 16(5): 490-500.

Faye, Lindsay 2012: Why Sherlock? Narrator Investment in the BBC Series. Stein, Louisa Ellen \& Kristina Busse (eds.), Sherlock and Transmedia Fandom. Essays on the BBC series. Jefferson, NC: McFarland. 1-7.

Garde-Hansen, Joanne \& Kristyn Gorton 2013: Emotion Online: Theorizing Affect on the Internet. Houdmills \& New York: Palgrave Macmillan.

Harrington, Cheryl \& Denise Bielby 1995: Soap Fans: Pursuing Pleasure and Making Meaning in Everyday Life. Philadelphia: Temple University Press.

Harvey, CB 2012: Sherlock's Webs, What the Detective Remembered from the Doctor about Transmediality. - Stein, Louisa Ellen \& Kristina Busse (toim.), Sherlock and Transmedia Fandom. Essays on the BBC series. Jefferson, NC: McFarland. 118-132.

Hastie, Amelie 2007: The epistemological stakes of Buffy the Vampire Slayer. Television criticism and marketing demands. - Levine, Elana \& Lisa Parks (eds.), Undead TV. Essays on Buffy the Vampire Slayer. Durham: Duke University Press. 74-95.

Heimo, Anne \& Kaarina Koski 2014 [online]: Internet Memes as Statements and Entertainment. Folklore Fellows Network 44: 4-12. <www.folklorefellows.fi> [24.9.2017]

Hills, Matt 2012: Sherlock's Epistemological Economy and the Value of "Fan" knowledge. How Producer-Fans Play The (Great) Game of Fandom. - Stein, Louisa Ellen \& Kristina Busse (toim.), Sherlock and Transmedia Fandom. Essays on the BBC series. Jefferson, NC: McFarland, 27-40.

Hills, Matt 2014: Rebranding Doctor Who and reimagining Sherlock: 'Quality' television as 'makeover TV drama'. International Journal of Cultural Studies, 18(3): 317-331. Hoilman, Mindy 2012 [online]: Talking back to the Culture: The Growing Literary Subculture of Fan Fiction. <http://faculty.etsu.edu/ odonnell/2012fall/engl3130/ student essays/fan fiction.pdf $>$ [13.3.2017]

Jenkins, Henry 1992: Textual Poachers. New York \& London: Routledge. 
Jenkins, Henry 2006: Fans, Bloggers, Gamers. New York: New York University Press.

Jenkins, Henry 2008: Convergence Culture: Where Old and New Media Collide. New York: New York University Press.

Jensen, Joli 1992: Fandom as Pathology: The Consequences of Characterization. Teoksessa: Lisa A. Lewis (eds.). The Adoring Audience. Fan Culture and Popular Media. London and New York: Routledge. 9-29.

Jensen, Louise 2014: Representations of Sherlock Holmes: A Study of Sherlock Holmes' New Trademarks as a Sex symbol, Action hero, and Comedian in the 21st Century. Master's thesis, Aalborg University.

Koski, Kaarina 2011 [online]: Mediakulttuurin murros, YouTube ja folklore. Elore 18(1): 14-27. <http://www.elore.fi/arkisto/1 11/kats koski.pdf> [24.9.2017]

Kustritz, Anne \& Melanie E. S. Kohnen 2012: Decoding the Industrial and Digital City. Visions of Security in Holmes' and Sherlock's London. - Stein, Louisa Ellen \& Kristina Busse (eds.), Sherlock and Transmedia Fandom. Essays on the BBC series. Jefferson, NC: McFarland. 85-100.

Kyrölä, Katariina 2010: The Weight of Images. Affective Engagements with Fat Corporeality in the Media. Turku: University of Turku.

Logan, Robert K. 2010: Understanding New Media. Extending Marshall McLuhan. New York: Peter Lang.

McLaughlin, Rebecca 2013: A Study in Sherlock: Revisiting the Relationship between Sherlock Holmes and Dr. John Watson. Virtual Commons. Bridgewater, MA: Bridgewater State University.

McLuhan, Marshall 1994 [1964]: Understanding Media: the Extensions of Man. Reprint edition. Cambridge, MA: MIT Press.

Nikunen, Kaarina 2008: Televisio ja fanius - Verkon varassa? Teoksessa: Kaarina Nikunen (toim.). Fanikirja. Tutkimuksia nykykulttuurin fani-ilmiöistä. Jyväskylä: Nykykulttuurin tutkimuskeskuksen julkaisuja. 184-199.

Nikunen, Kaarina 2005: Faniuden aika. Kolme tapausta television-ohjelmien faniudesta. Tampere: Tampereen yliopisto.

Paasonen, Susanna 2017 [online]: Affekti suhteina ja intensiteettinä. Tieteessä tapahtuu 35(2), <https://journal.fi/tt/article/view/62067> [24.9.2017]

Polasek, Ashley D. 2012: Winning "The Grand Game". Sherlock and the Fragmentation of Fan Discourse. - Stein, Louisa Ellen \& Kristina Busse (eds.), Sherlock and Transmedia Fandom. Essays on the BBC series. Jefferson, NC: McFarland. 41-54.

Pöysä, Jyrki 2015: Lähiluvun tieto. Näkökulmia kirjoitetun muistelukerronnan tutkimukseen. Joensuu: Suomen Kansantietouden Tutkijain Seura.

Scodari, Christine \& Jenna L. Felder 2000: Creating a pocket universe. "Shippers," fan fiction, and The X-Files online. Communication Studies 51(3): 238-257.

Scott-Zechlin, Ariana 2012: "But It's the Solar System!" Reconciling Science and Faith Through Astronomy. - Stein, Louisa Ellen \& Kristina Busse (eds.), Sherlock and Transmedia Fandom. Essays on the BBC series. Jefferson, NC: McFarland. 56-69. 
Shifman, Limor 2014: Memes in Digital Culture. Cambridge, MA: MIT Press.

Stanfill, Mel 2013: "They're Losers, but I Know Better". Intra-Fandom Stereotyping and the Normalization of the Fan Subject. Critical Studies in Media Communication 30(2): 117-134.

Stein, Louisa Ellen \& Kristina Busse 2012: Introduction. The Literary, Televisual and Digital Advetures of Beloved Detective. - Stein, Louisa Ellen \& Kristina Busse (eds.), Sherlock and Transmedia Fandom. Essays on the BBC series. Jefferson, NC: McFarland. 9-24.

The Baker Street Journal 2017 [online]: <http://www.bakerstreetjournal.com/ grandgamev2 .html\#toc> [30.10.2017].

Vanhanen, Elise 2015 [online]: Lähiluku muistelukirjoituksen menetelmänä. Elore 22(2). $\quad \leq$ http://www.elore.fi/lahiluku-muistelukirjoitustenanalyysimenetelmana/> [26.9.2017]

Östman, Sari 2015: "Millaisen päivityksen tästä sais?" Elämäjulkaisijuuden kulttuurinen omaksuminen. Jyväskylä: Nykykulttuurin tutkimuskeskus.

Filosofian tohtori Tanja Sihvonen on peli- ja mediatutkija, ja hän työskentelee viestintätieteiden professorina Vaasan yliopistossa.

Filosofian maisteri Meniina Wik on viestintätieteiden jatko-opiskelija Vaasan yliopistossa. 